\title{
Explosive eruptive history of Pantelleria, Italy: repeated caldera collapse and ignimbrite emplacement at a peralkaline volcano
}

Nina J. Jordan ${ }^{a}$, Silvio G. Rotolo ${ }^{b, c}$, Rebecca Williamsa, ${ }^{a}$ Fabio Speranzae, William C. Mclntosh ${ }^{f}$, Michael J. Branney ${ }^{a}$, Stéphane Scaillet ${ }^{g}$

a University of Leicester, Department of Geology, University Road, Leicester, LE1 7RH, UK b Università di Palermo, Dip. Scienze della Terra e del Mare (DISTEM), Via Archirafi 22, 90123 Palermo, Italy c Istituto Nazionale di Geofisica e Vulcanologia (INGV), Sezione di Palermo, Via U. La Malfa 153, 90146 Palermo, Italy d University of Hull, Geology, School of Environmental Sciences, Cottingham Road, HULL, HU6 7RX, UK e Istituto Nazionale di Geofisica e Vulcanologia, Via di Vigna Murata 605, 00143 ROMA, Italy f NM Bureau of Geology \& Mineral Resources, New Mexico Tech, 801 Leroy Place, Socorro, NM 87801 , USA $\mathrm{g}$ Institut des Sciences de la Terre d'Orléans (ISTO), Campus Géosciences, 1A Rue de la Ferollerie, 45071 Orléans Cedex 2, France

Corresponding author: Nina Jordan (nji5@le.ac.uk or nina.jordan@rwth-aachen.de)

\section{Abstract}

A new, pre-Green Tuff ( $46 \mathrm{ka}$ ) volcanic stratigraphy is presented for the peralkaline Pantelleria Volcano, Italy. New ${ }^{40} \mathrm{Ar} /{ }^{39} \mathrm{Ar}$ and paleomagnetic data are combined with detailed field studies to develop a comprehensive stratigraphic reconstruction of the island. We find that the pre-46 ka succession is characterized by eight silica-rich peralkaline (trachyte to pantellerite) ignimbrites, many of which blanketed the entire island. The ignimbrites are typically welded to rheomorphic, and are often associated with lithic breccias and/or pumice deposits. They record sustained radial pyroclastic density currents fed by low pyroclastic fountains. The onset of ignimbrite emplacement is typically preceded (more rarely followed) by pumice fallout with limited dispersal, and some eruptions lack any associated pumice fall deposit, suggesting the absence of tall eruption columns. Particular attention is given to the correlation of well-developed lithic breccias in the ignimbrites, interpreted as probable tracers of caldera collapses. They record as many as five caldera collapse events, in contrast to the two events reported to date. Inter-ignimbrite periods are characterised by explosive and effusive eruptions with limited dispersal, such as small pumice cones, as well as pedogenesis. These periods have similar characteristics as the current post-Green Tuff activity on the island, and, while not imminent, it is reasonable to postulate the occurrence of another ignimbrite-forming eruption sometime in the future. 
Highlights

- $\quad$ First complete spatial and temporal pre-46 ka volcanic history of the island

- $\quad$ Small-scale background activity punctuated by 9 ignimbrite eruptions

- 5 caldera collapse events, 3 more than previously defined

- $\quad$ Future large explosive eruptions cannot be ruled out

Keywords

Peralkaline volcanism; Pantelleria; ignimbrites; caldera collapse; eruptive history; ${ }^{40} \mathrm{Ar} /{ }^{39} \mathrm{Ar}$ dating

\section{Introduction}

Pantelleria in Italy is the type locality of the strongly peralkaline rhyolite pantellerite and a widelyquoted example of bimodal alkaline magmatism. Despite its small size $\left(83 \mathrm{~km}^{2}\right)$ and youthfulness ( $<400$ kyr subaerial activity), it has undergone a remarkably complex evolutionary history. Due to its superb coastal sections, it has great potential to further our understanding of peralkaline volcanoes. A major step in tracing the magmatic history and physical volcanology is to properly understand the volcanic stratigraphy. This paper presents a new comprehensive eruption stratigraphy for Pantelleria volcano, and interprets the major pre-46 ka explosive eruptions for the first time.

Peralkaline silicic magmas (here defined as silica-saturated and with a peralkalinity index $>1$ ) are commonly found in extensional tectonic settings and differ from peraluminous and metaluminous silicic magmas in their eruptive behaviour and low melt viscosity. As a consequence, their deposits tend to be welded and rheomorphic (e.g. Mahood, 1984). As our understanding of peralkaline volcanoes has developed through recent stratigraphic studies, we find that they are increasingly characterised by large ignimbrite-forming eruptions and caldera collapse (e.g. Buckhorn Caldera, USA: Parker \& White, 2008; Aluto, Ethiopia: Hutchison et al. 2016b; Embu County, Kenya: Claessens et al. 2016). Peralkaline magmas are typically volatile-rich (Lowenstern \& Mahood, 1991; Scaillet \& Macdonald, 2001; Gioncada \& Landi, 2010; Neave et al., 2012; Lanzo et al., 2013), and thus have the potential to dramatically impact their environment (e.g. Claessens et al., 2016) and have recently been linked to bottlenecks in human evolution (Basell, 2008; Hutchison et al., 2016a). Here we present a new, comprehensive eruption stratigraphy for the peralkaline Pantelleria Volcano, Italy.

Stratigraphic correlations on Pantelleria have been hampered by fragmented exposures and pronounced lateral variability within any single eruptive unit. Also, radioisotopic dating efforts are commonly compromised by xenocrystic contamination. Recently, the paleosecular variation of the geomagnetic field recorded by welded ignimbrites has been successfully used as a correlative tool for the younger ignimbrites (Speranza et al., 2012). 
While the most recent stratigraphic studies (Speranza et al., 2012; Rotolo et al., 2013) made great advances in the ignimbrite stratigraphy using paleomagnetic and radioisotopic techniques, problems remain with confusing and inconsistently named units (Units $D, F, I, M, P, Q, S, Z$ ) and limited crossisland correlations, which hinder interpretations of the physical volcanology. No type sections have been defined to date and due to vertical cliff sections some sampling locations have been ambiguous. Many of the older units have been omitted in recent reviews. This paper applies formal stratigraphic guidelines and uses detailed field data (from the island's spectacular sea cliffs) combined with paleomagnetic data and ${ }^{40} \mathrm{Ar} /{ }^{39} \mathrm{Ar}$ dates to compile a new eruptive history, thereby for the first time extending the record back in time to the beginning of ignimbrite activity on the island. Geochemical data for the ignimbrites will be presented separately in a forthcoming paper.

\section{Geological setting \& history}

The Italian island of Pantelleria lies on a submerged NW-trending continental rift between Sicily and Tunisia (Villari, 1974), in the foreland of the Africa-Europe collision zone (Figure 1). The island is made up of a bimodal suite of basaltic and trachytic to rhyolitic lavas and pyroclastic deposits (Civetta et al., 1984). The majority of exposed eruptive products are felsic, but submarine parts of the volcano are mostly basaltic (Fulignati et al., 1997). No eruption has occurred on the island in historic times but a small basaltic submarine eruption was witnessed $4 \mathrm{~km}$ west of Pantelleria in 1891 (Washington, 1909) and other potentially active submarine volcanic areas are known in the Sicily Channel (e.g. Coltelli et al., 2016). Measured rates of ground deformation, temperature, steam production and $\mathrm{CO}_{2}$ and $\mathrm{H}_{2} \mathrm{~S}$ emission are consistent with the presence of an active hydrothermal system and shallow magma reservoir (at $\sim 4 \mathrm{~km}$ depth) which is currently in a cooling and deflating state (Gianelli \& Grassi, 2001; Mattia et al., 2007).

It is not known when the volcano began erupting because more than half of it lies beneath the sea. The oldest published radioisotopic date ( $517 \pm 19 \mathrm{ka}$, Ar-Ar plateau age) is from a lithic inclusion in an ignimbrite (Rotolo \& Villa, 2001). Subaerial effusive and explosive small-scale activity along much of the south coast dates from 324-239 ka (feldspar and glass K-Ar, Mahood \& Hildreth, 1986). Between $\sim 190$ and 46 ka a series of ignimbrites were erupted over all or much of the island, the last one being the Green Tuff which mantles all older stratigraphy (Wolff \& Wright, 1981; Mahood \& Hildreth, 1986; Scaillet et al., 2013; Williams et al., 2014).

In addition to the ignimbrites, more than 20 silicic explosive eruptions were vented from small eruptive centres (mostly intra-caldera) and fed by pantellerite magmas, usually as pumice-fall deposits but at some centres activity ended with pantellerite lava (Mahood \& Hildreth, 1986; Orsi et al., 1989; Orsi et al., 1991; Rotolo et al., 2007; Scaillet et al., 2011). These are sometimes termed 
strombolian (in terms of dispersal) but they are composed of pumice lapilli rather than basaltic scoria as is more typically associated with strombolian activity elsewhere.

High-precision Ar/Ar data (Scaillet et al., 2011) capture a declining eruptive pace for the last $15 \mathrm{kyr}$ in eruptive activity from 3.5 to 0.8 events per kyr.

Based on topographic scarps, two caldera collapse events had been proposed: one caused by the eruption of a 'welded pyroclastic breccia' ( 140 ka) and the other by the $46 \mathrm{ka}$ Green Tuff eruption (Cornette et al., 1983; Civetta et al., 1984; Mahood \& Hildreth, 1986; Rotolo et al., 2013).

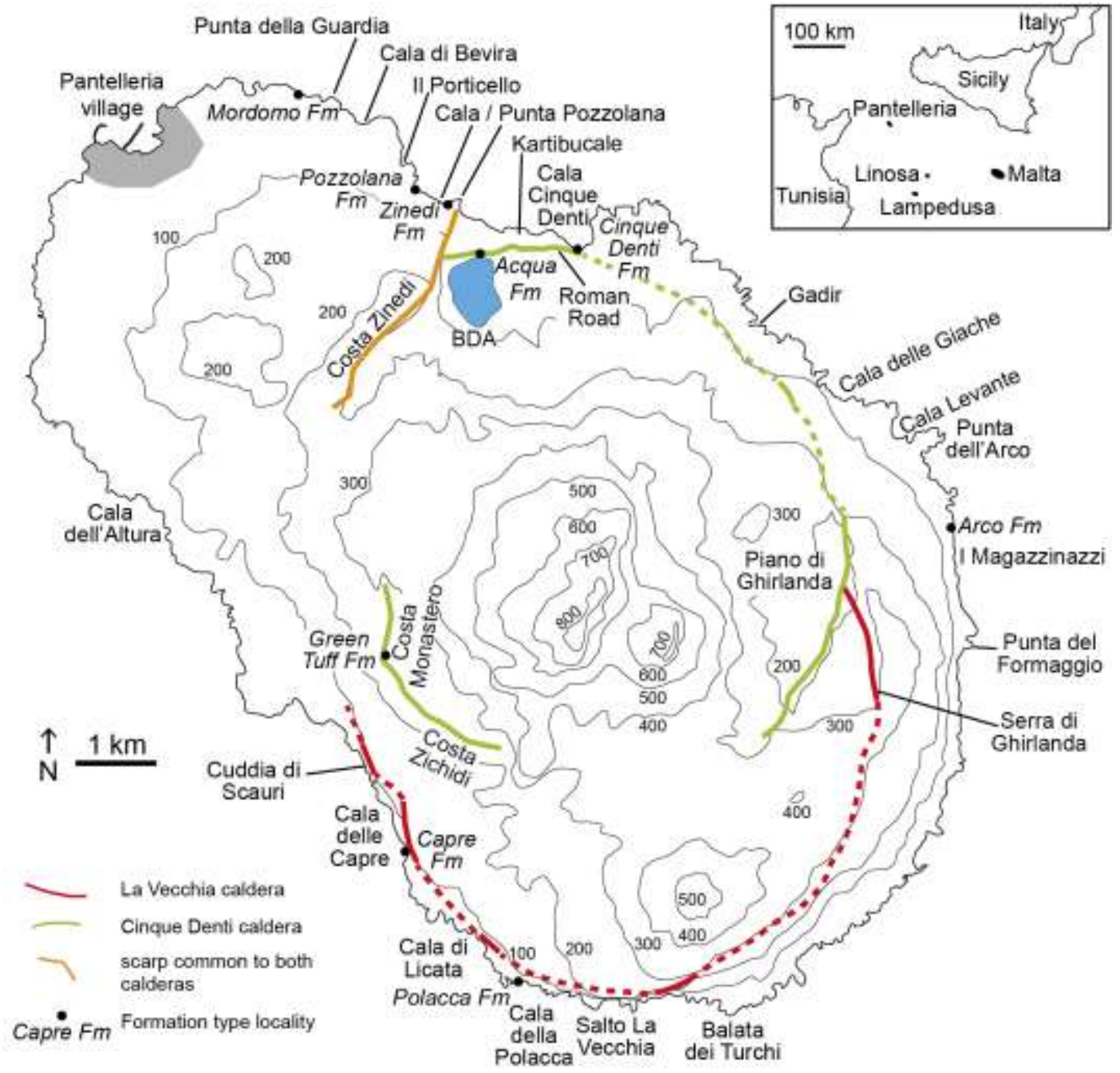

Figure 1. Map of Pantelleria showing location names, topography, proposed calderas (after Mahood \& Hildreth, 1986) and type localities of ignimbrite formations (in italics; this study). The pre-Green Tuff stratigraphy is only exposed in sea cliffs and caldera scarps. Fm: formation; BDA: Bagno Dell'Acqua caldera lake.

3 Previous definition of ignimbrites

Previously, the pyroclastic succession on Pantelleria has been divided into various informal 'units', depicted by letters ('B', ' $C$ ' etc.: Wright, 1980). Our new definition of the ignimbrites (and their associated deposits such as pumice falls) as a soil-bound eruption-unit reduces and simplifies the 
number of names proposed previously (e.g. for the Mordomo Formation: 'Unit D' and ' $Z$ ' of Mahood \& Hildreth, 1986; variously 'Unit C', 'D' and 'E' of Wright, 1980, see Table 1), in agreement with field, palaeomagnetic and geochronological results (La Felice et al., 2009; Williams, 2010; Speranza et al., 2012; Rotolo et al., 2013). Their aerial distribution had never been mapped before and lithofacies not been studied in detail.

We adopt the newest age determinations (Rotolo et al., 2013) as the preferred age for units that have not been dated as part of this study. 
Table 1. Equivalents of eruption-units of this work with previous studies and preferred radioisotopic dating results.

\begin{tabular}{|c|c|c|c|c|c|}
\hline This study & $\begin{array}{l}\text { Speranza et al. } \\
\text { (2012), Rotolo et } \\
\text { al. (2013) }\end{array}$ & Mahood \& Hildreth, 1986 & Wright, 1980 & $\begin{array}{l}\text { Previous age (K-Ar from } \\
\text { Mahood \& Hildreth (1986) } \\
\text { unless stated otherwise) }\end{array}$ & $\begin{array}{l}\text { Preferred age (Ar-Ar unless } \\
\text { stated otherwise) }\end{array}$ \\
\hline $\begin{array}{l}\text { Mordomo } \\
\text { Formation }\end{array}$ & 'D'/'Z' & 'Z' \& 'D' & 'C', 'D', 'E' & $\begin{array}{l}88 \text { ka (Ar-Ar, La Felice et al., } \\
\text { 2009). 78, 84, 88, } 97 \text { ka }\end{array}$ & 85 ka (Rotolo et al., 2013) \\
\hline Acqua Formation & 'F' & $\begin{array}{l}\text { 'Unit F' at Punta della } \\
\text { Guardia and on the south } \\
\text { coast of the island; 'Unit Q' } \\
\text { at Gadir \& Kartibucale } \\
\text { topographic caldera wall }\end{array}$ & $\begin{array}{l}\text { 'F'; ' } G \text { ' of section } 7 \\
\& 9\end{array}$ & $\begin{array}{l}\text { 101, 104, 105, 110, 113, } \\
116 \mathrm{ka}\end{array}$ & 107 ka (Rotolo et al., 2013) \\
\hline $\begin{array}{l}\text { Cinque Denti } \\
\text { Formation }\end{array}$ & ‘ $\mathrm{P}^{\prime}$ & $\begin{array}{l}\text { 'Unit Q' at Bue Marino, } \\
\text { Punta della Guardia, Cala } \\
\text { Rossa, Cala di Bevira; 'Unit P' } \\
\text { at Cala Cinque Denti, Gadir, } \\
\text { Costa Zinedi \& Kartibucale } \\
\text { caldera wall segments }\end{array}$ & $\begin{array}{l}\text { 'G'; 'g' of section } 7 \\
\& 9 ; \text {; } U \text { ' of section } \\
10 \text { (?) }\end{array}$ & $\begin{array}{l}\text { 123, 128, } 135 \mathrm{ka}(\mathrm{Ar}-\mathrm{Ar}, \\
\text { Rotolo et al. 2013). 132, 133, } \\
134 \mathrm{ka}\end{array}$ & 128 ka (this study) \\
\hline Capre Formation & $\begin{array}{l}\text { 'Welded Breccia' } \\
\text { (Br1) }\end{array}$ & 'Breccia' & & $\begin{array}{l}\text { 140, } 146 \mathrm{ka} \text { (Ar-Ar, Rotolo et } \\
\text { al. 2013). 104, } 127 \mathrm{ka}\end{array}$ & 138 ka (this study) \\
\hline Arco Formation & 'S' & 'S' & & $\begin{array}{l}171 \text { ka (Ar-Ar, Rotolo et al. } \\
\text { 2013). 162, 164, 195, } 209 \text { ka }\end{array}$ & 179 ka (this study) \\
\hline $\begin{array}{l}\text { Polacca } \\
\text { Formation }\end{array}$ & 'M’' & $' M \prime$ & 'G' of section 15 & $\begin{array}{l}181 \text { ka ka (Ar-Ar, Rotolo et al. } \\
\text { 2013). 169, 172, 177, } 178 \text { ka }\end{array}$ & 187 ka (this study) \\
\hline $\begin{array}{l}\text { Pozzolana } \\
\text { Formation }\end{array}$ & & 'H’(?) & ‘ $\mathrm{H}^{\prime}$ & & No age determined \\
\hline Zinedi Formation & & ‘' & ‘' & & $\begin{array}{l}189 \text { ka (K-Ar age of } \\
\text { Mahood \& Hildreth, 1986) }\end{array}$ \\
\hline
\end{tabular}




\section{Methods}

\subsection{Field methods}

Eruption-units were logged and lithofacies (Table 2) assigned based on grain size, lithology and sedimentary structures or fabric following the non-genetic, non-stratigraphic terminology of Branney \& Kokelaar (2002). The term pyroclastic density current (PDC) is used for any type of gaseous current carrying pyroclastic material, and we use ignimbrite for the pumiceous deposit of a PDC.

The most common lithofacies in the rocks studied here is eutaxitic massive lapilli-tuff (emLT), i.e. a welded non-bedded ash deposit containing lapilli-size clasts (ash>lapilli). Eruption-units have been defined based on the presence of weathering horizons (palaeosols), designated as formations and given a type locality for which they were named (following Salvador, 1994). The Green Tuff Formation has retained its name as it is already well established in the literature. Each formation typically records a major explosive eruption and is bounded by weathering horizons ('soils') that record intervening periods of repose, whereas the members generally record a distinctive phase of an eruption (e.g. a pyroclastic fall or pyroclastic density current event). This interpretation significantly differs from previously published stratigraphy studies (e.g. Civetta et al., 1984; Mahood \& Hildreth, 1986) and helps to overcome some of the correlation problems encountered by previous workers. For example, a pumice fall or lithic breccia will always occur at the same stratigraphic level and can thus help to identify the associated ignimbrite where it alone is not sufficiently distinctive. Maximum crystals (MX), maximum pumice clasts (MP) and maximum lithic clasts (ML) represent an average length of the 20 largest crystals, juvenile clasts (pumice clasts) and lithic clasts, respectively. Place names are from sheet 256 of the 1972 map of Italy ( $2^{\text {nd }}$ edition, series M891, Italian Military Geographic Institute) and UTM coordinates are in European Datum 1950. 
Table 2. Description and interpretation of common lithofacies in products from large Pantescan eruptions. Modified from Branney \& Kokelaar (2002).

\begin{tabular}{|c|c|c|}
\hline Lithofacies & Description & Interpretation \\
\hline $\begin{array}{l}\text { eutaxitic massive } \\
\text { lapilli-tuff (emLT) }\end{array}$ & $\begin{array}{l}\text { Poorly sorted with variable } \\
\text { proportions of lithic lapilli set in a } \\
\text { devitrified (rarely glassy) ash } \\
\text { matrix. Rare fiamme lapilli. Clasts } \\
\text { are matrix-supported. Lacks } \\
\text { internal stratification. Variations: I: } \\
\text { lithic-rich. r: rheomorphic (i.e. with } \\
\text { ductile stretching lineation, prolate } \\
\text { vesicles and flow folds) }\end{array}$ & $\begin{array}{l}\text { Massive nature, poor sorting and absence of } \\
\text { tractional structures indicate rapid } \\
\text { progressive aggradation from a high- } \\
\text { concentration fluid escape-dominated } \\
\text { depositional flow-boundary of a PDC; clast } \\
\text { population comprises primary juvenile } \\
\text { material; diffuse bedding results from local } \\
\text { current unsteadiness, non-uniformity and } \\
\text { the development of granular-flow dominated } \\
\text { flow-boundaries. }\end{array}$ \\
\hline lithic breccia (IBr) & $\begin{array}{l}\text { Much more lithic-rich compared to } \\
\text { emLT, usually clast-supported with } \\
\text { little to no ashy matrix. Clasts are } \\
\text { heterolithic and typically } \\
\text { subangular to subrounded. May } \\
\text { grade vertically and/or laterally } \\
\text { into emLT. }\end{array}$ & $\begin{array}{l}\text { A coarse facies of ignimbrite, deposited } \\
\text { through the lower flow boundary of a PDC. } \\
\text { Blocks in IBr can be derived from (i) erosion } \\
\text { or collapse of the eruption conduit and/or } \\
\text { vent walls; (ii) avalanches into the pyroclastic } \\
\text { current; and (iii) erosion of substrate by the } \\
\text { density current. }\end{array}$ \\
\hline $\begin{array}{l}\text { scoria agglomerate } \\
\text { (scAg) }\end{array}$ & $\begin{array}{l}\text { Like IBr but with abundant large } \\
\text { fluidal-shaped juvenile bombs, } \\
\text { some scoriaceous, and subordinate } \\
\text { lithic blocks. May grade vertically } \\
\text { and/or laterally into emLT. }\end{array}$ & $\begin{array}{l}\text { Similar to } \mathrm{IBr} \text {, with higher content of cognate } \\
\text { clasts. }\end{array}$ \\
\hline $\begin{array}{l}\text { diffuse-bedded } \\
\text { lapilli-tuff (dbLT) }\end{array}$ & $\begin{array}{l}\text { Similar to emLT with discontinuous } \\
\text { sub-parallel or low-angle diffuse } \\
\text { bedding, commonly defined by } \\
\text { lithic horizons. May grade vertically } \\
\text { and/or laterally into emLT. }\end{array}$ & $\begin{array}{l}\text { Similar as for emLT. Diffuse bedding results } \\
\text { from current unsteadiness, perhaps in } \\
\text { granular flow-dominated flow boundaries, } \\
\text { while the discontinuous nature and lateral } \\
\text { thickness variations reflect current non- } \\
\text { uniformity }\end{array}$ \\
\hline $\begin{array}{l}\text { cross-stratified lapilli- } \\
\text { tuff (xsLT) }\end{array}$ & $\begin{array}{l}\text { Similar to emLT with low-angle } \\
\text { cross-stratification; millimetre- } \\
\text { centimetre thick strata }\end{array}$ & $\begin{array}{l}\text { Deposited from traction-dominated flow- } \\
\text { boundaries of fully dilute PDCs; low-angle } \\
\text { truncations record erosion due to current } \\
\text { unsteadiness, turbulent eddies or the } \\
\text { passage of successive currents. }\end{array}$ \\
\hline $\begin{array}{l}\text { massive pumice } \\
\text { lapilli ( } \mathrm{mpL} \text { ) }\end{array}$ & $\begin{array}{l}\text { Clast-supported well-sorted } \\
\text { angular pumice lapilli with } \\
\text { subordinate lithic lapilli. No matrix. } \\
\text { Variation: bpL: bedded pumice } \\
\text { lapilli }\end{array}$ & $\begin{array}{l}\text { Fall deposit from an eruption column. } \\
\text { Hydraulic sorting during airborne phase } \\
\text { results in light large clasts being deposited } \\
\text { with small dense clasts. }\end{array}$ \\
\hline
\end{tabular}

\subsection{Paleomagnetic directions}

We paleomagnetically sampled five new sites in the ignimbrites on Pantelleria, collecting 15 oriented cores at each site. Sampling methods, laboratory measurements techniques and instruments were the same as those detailed by Speranza et al. (2012), who sampled 23 sites in different ignimbrites and correlated them by evaluating the paleomagnetic directions. We sampled one site $(\operatorname{Cos} 36$, see Table A.1 in Appendix for coordinates) in the Pozzolana Formation at Punta Pozzolana, the Arco (Cos37) and Polacca (Cos35) Formations at Salto La Vecchia, and two ignimbrites (Cos39 and 42) 
presumed to correlate with the Arco and Polacca Formations in the sea cliff beneath Scauri village, just below the Green Tuff. For the nonwelded Zinedi Formation (Cos38) we were unable to get satisfactory results.

\section{$4.3{ }^{40} \mathrm{Ar} /{ }^{39} \mathrm{Ar}$ methods and results}

Feldspar separates from six samples were prepared at the University of Leicester by coarsely crushing the rock, rinsing with tap water, drying and then sieving. Crystals were picked from the $500 \mu \mathrm{m}$ to $1 \mathrm{~mm}$ fraction. To remove mafic minerals and glass, the crushed material was screened with a hand magnet and then fed through a Frantz isodynamic separator at increasing strengths until only feldspar was left. This portion was leached in $3 \mathrm{~N} \mathrm{HNO}_{3}$ acid in an ultrasonic bath for 30 40 minutes to remove adhering glass and any surface weathering. Afterward the sample was rinsed with distilled water three times and then dried. 50-100 feldspar crystals were hand-picked under a binocular microscope that were euhedral, free from inclusions and without adhering glass.

Sanidine separates and flux monitors (Fish Canyon Tuff sanidine, 28.201 Ma, Kuiper et al., 2008) were irradiated in machined aluminum discs along with flux monitors for 60 minutes at the USGS TRIGA reactor in Denver, CO. Following irradiation, feldspar separates and monitors were analyzed at the New Mexico Geochronology Research Laboratory using a Thermo Argus VI multicollector mass spectrometer. Analytical parameters are summarized in the footnotes of Table A.3. Single crystals of flux monitors $(n=6)$ and unknowns ( $n=15-23)$ were fused using a 75 watt $\mathrm{CO}_{2}$ laser. J-factors were determined from monitor analyses to a precision of $\pm 0.1 \%$.

Results from the six dated samples are summarized in the Appendix (Table A.2, A.3 and Figure A.2), and complete analytical data are detailed in Table A.4. Four of the six samples (140612-2, 060912, 310512-2, and 160712-3) yielded relatively simple age-probability distributions with the majority of crystals forming a single age population, after rejecting a minority of crystals with anomalously old ages (likely older xenocrysts) or anomalously young ages (likely due to slight alteration or minor unremoved matrix glass). Weighted-mean ages for these for samples range from 137.9 to $257 \mathrm{ka}$, with small uncertainties ranging from \pm 0.8 to $\pm 2 \mathrm{ka}$. We interpret these weighted-mean ages as accurate eruption ages.

Two of the six samples yielded slightly more complex results. Sample 300511 yielded a tight cluster of high-radiogenic-yield (>50\%) ages near $127.5 \mathrm{ka}$, accompanied by a group of lower radiogenicyield data points ranging from slightly younger to much older (112 \pm 2 ka to $300 \pm 66 \mathrm{ka}$ ) than the high-radiogenic-yield cluster. These low-radiogenic-yield scattered single-crystal ages may be due to undetected melt inclusions bearing small amounts of excess ${ }^{40} \mathrm{Ar}$. We interpret the mean age of the higher-radiogenic-yield crystals (127.5 $\pm 1.3 \mathrm{ka}$ ) to represent an accurate eruption age for this unit. 
Sample 11 yielded a relatively wide range of single-crystal ages, ranging from 130 ka to $392 \mathrm{ka}$.

Unlike the other samples, the youngest crystals do not form a tight single population that is clearly distinct from older, likely xenocrystic, crystals. The youngest three crystals were somewhat arbitrarily chosen to calculate the weighted mean age of $133 \pm 5 \mathrm{ka}$. The relatively large uncertainty is due to the age scatter among the three selected crystals. We interpret this result as a fairly accurate measure of the eruption age, but have less confidence in this result compared to the other five samples.

\section{A new ignimbrite stratigraphy}

Nine ignimbrite formations are here defined and correlated over most of Pantelleria (Figure 2). These are, from the youngest to the oldest: Green Tuff Formation (defined by Williams (2010), Mordomo Formation, Acqua Formation, Cinque Denti Formation, Capre Formation, Arco Formation, Polacca Formation, Pozzolana Formation and Zinedi Formation. Anorthoclase feldspar is by far the most abundant phenocryst in all of them, followed by clinopyroxene. Other crystal components are detailed, in order of abundance, on the general vertical stratigraphy (Figure 2).

Since there has already been a large amount of work done on the Green Tuff Formation, the focus of this study will be on the less-studied pre-Green Tuff ignimbrites. They will be presented from youngest to oldest because of better exposure of the younger rocks. 


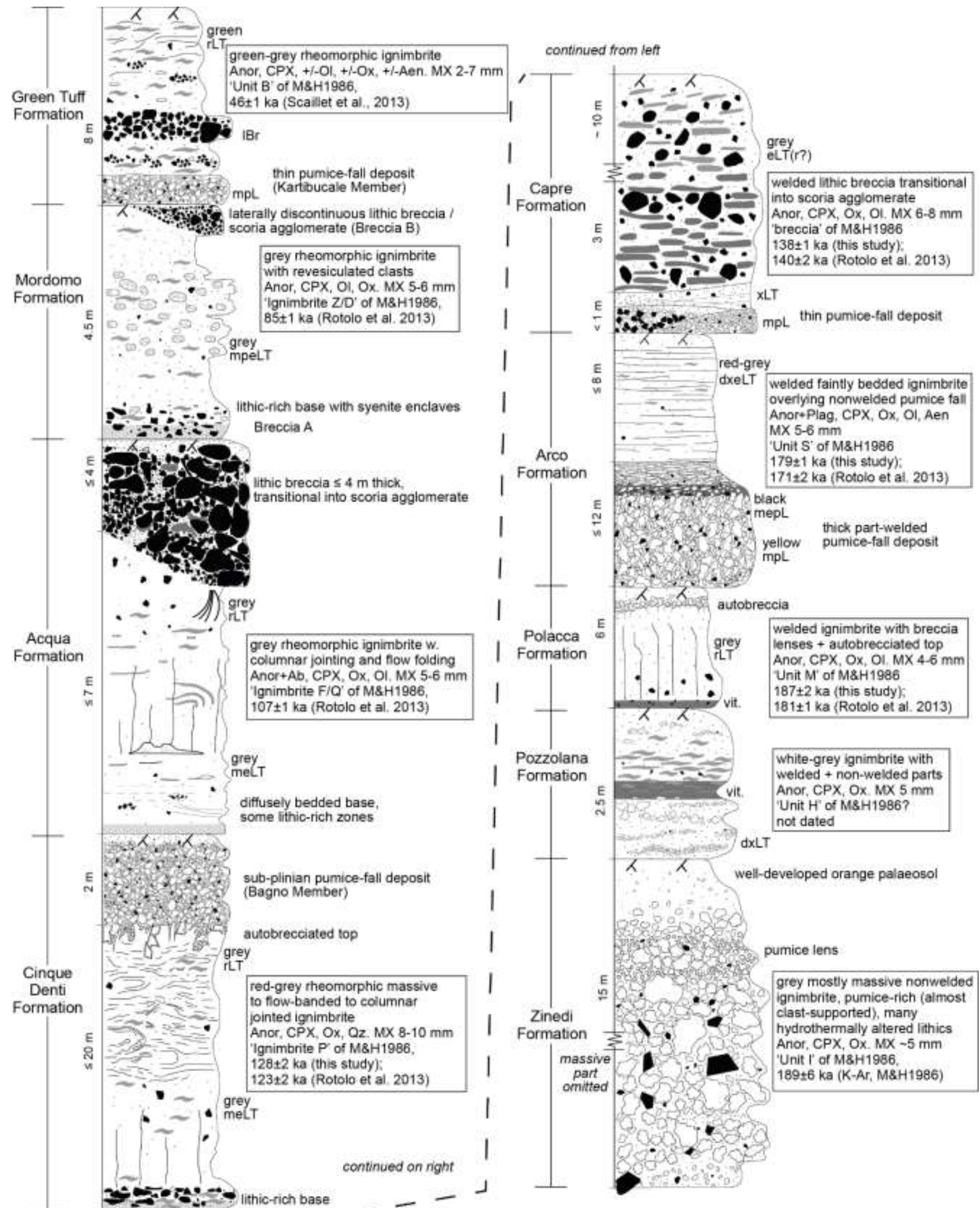

Figure 2. General vertical stratigraphy of ignimbrite-producing eruptions on Pantelleria (this study). Note different scale on each unit. Logs are from the type localities of each unit. Abbreviations: M\&H 1986= Mahood \& Hildreth, 1986, Anor= anorthoclase, CPX= clinopyroxene, Ol= olivine, Ox= Fe-Ti oxides (magnetite and/or ilmenite), Aen= aenigmatite, $\mathrm{Ab}=$ albite, $\mathrm{Qz}=$ quartz, $\mathrm{Plag}=$ plagioclase. 


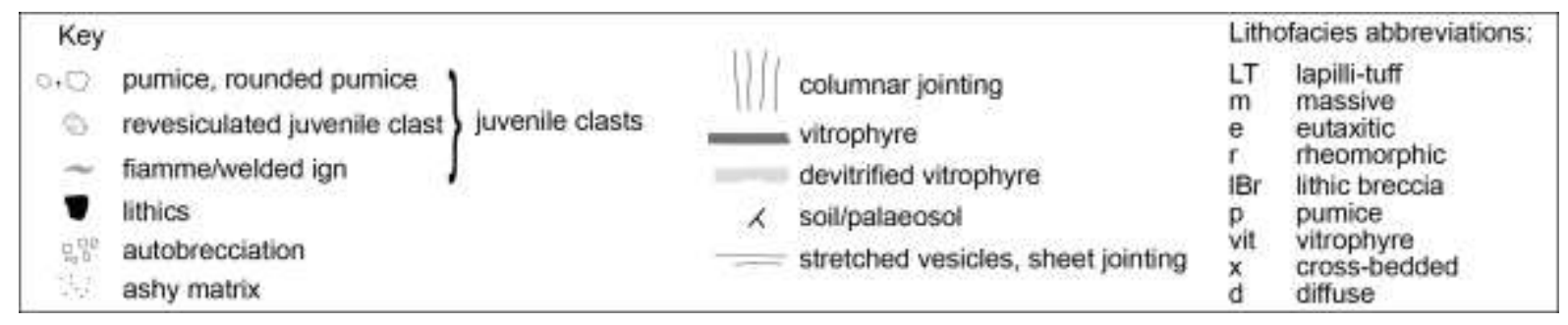

\subsection{Green Tuff Formation}

\subsubsection{Definition}

The 46 ka Green Tuff Formation has been defined as consisting of (i) the Green Tuff Ignimbrite, on average $4 \mathrm{~m}$ thick, and (ii) the Kartibucale Member, $<1 \mathrm{~m}$ thick (Williams, 2010). ). The type section for this formation is on the Costa Monastero caldera scarp in the west of Pantelleria (Figure 1), though lateral variations mean that particular lithofacies are best observed at different locations (e.g. the lower part near the caldera lake in the north of Pantelleria). The formation is capped by a weathering horizon that is itself locally overlain by younger eruption deposits and overlies the weathering horizon in the top of the Mordomo Formation. Previous names include 'Green Ignimbrite' (Villari, 1974) and 'Green Tuff' (e.g. Wolff \& Wright, 1981). Detailed descriptions of the formation and its lateral variations are given in Williams (2010) and Williams et al. (2014).

\subsubsection{Lithofacies}

Description: The Kartibucale Member is a very well sorted pumice deposit of limited lateral distribution. It is overlain by a very poorly sorted, variably stratified, welded, eutaxitic lapilli-tuff with local lithic breccia lenses (Green Tuff Ignimbrite; Figure 2). Low-angle cross stratification, lithic lenses, crystal rich layers, vitroclastic textures, and pumice concentration zones are well preserved, particularly near the base. Extensional lineations, sheath folds (Branney et al., 2004) and postdepositional vesiculation develop in the strongly welded and rheomorphic sections (typically in upper parts of the formation). Lithic breccia lenses are thin $(<1 \mathrm{~m})$, not laterally extensive and do not occur at the same horizon laterally through the deposit. Some lenses are comprised of lapilli to block-sized locally-derived lithic clasts, whereas others are mostly comprised of lapilli to block-sized plutonic lithic clasts (Williams, 2010). The formation is compositionally zoned from pantellerite at the base to trachyte at the top, with gradual upwards increases in the size and abundance of anorthoclase crystals (Williams et al., 2014).

Interpretation: The eruption began with fallout of pumice lapilli from a low eruption column and changed to pyroclastic fountaining feeding an initially unsteady and more dilute pyroclastic density current that evolved into a more steady, sustained granular-fluid based current that gradually spread across the entire island, and then retreated after the eruption climax (Williams et al., 2014). Hot, 
sticky pyroclasts in the current agglutinated rapidly upon deposition, and underwent intense shear from the overriding current and due to gravity, forming a range of rheomorphic fabrics and structures. There is no clear evidence for a single caldera-forming phase during the eruption but some of the breccia lenses may record reactivation of existing caldera scarps.

\subsection{Mordomo Formation}

\subsubsection{Definition}

The rhyolitic Mordomo Formation (new name) consists of a welded ignimbrite with local lithic breccias and less-welded zones. It is considered an eruption-unit because it is capped by a weathering horizon at the top and overlies a weathering horizon of an older eruption-unit (Acqua Formation). It is overlain by the Green Tuff Formation. The type section for this formation is a coastal section in the north of the Pantelleria, just E of Punta Mordomo after which it is named (Figure 1).

\subsubsection{Lithofacies}

Description: The type section at Mordomo comprises grey emLT with a lithic rich base (lemLT) containing abundant lapilli to block-sized plutonic clasts $(5 \mathrm{~cm}$ average, up to $12 \mathrm{~cm}$ ) and a basal vitrophyre (vit), in places devitrified to beige clay. Lithofaces pemLT occurs half way up section and contains characteristic banded, oval pumices of $40-60 \%$ vesicularity and plutonic lithic clasts (Figure 3). Vesicles in the pumices are arranged in layers and are as large as $1 \mathrm{~cm}$ in diameter, most are round and some are flattened. These clasts grade out towards the top of the unit, which comprises eLT and is characterised by abundant flattened, sub-horizontally oriented vesicles ranging from $<1$ to $4 \mathrm{~cm}$. There is a pale $<1 \mathrm{~cm}$ thick tuff layer $(\mathrm{mT})$ in the upper two-thirds of the ignimbrite. The Formation is capped by a dark red bed of lithic $(\sim 8 \mathrm{~cm})$ and juvenile lapilli $(\sim 3 \mathrm{~cm}$; average of 20 biggest clasts) in a tuff matrix (mLT), indicating an abrupt transition to a nonwelded deposit.

The Mordomo Formation has been correlated widely across the island (Figure 4) and shows great lateral variation of lithofacies present, and within lithofacies, e.g. in the amount of juvenile and lithic clasts and the presence or absence of the revesiculated pumice clasts. Thicknesses varies between $1 \mathrm{~m}$ and $\sim 7 \mathrm{~m}$ with the thin deposits generally occurring on top of topographic highs. Stratified horizons (exsLT) are laterally impersistent and most often occur on topographic highs.

The Mordomo Formation contains two distinct lithic breccias: one at the base of the unit (breccia A) and one at the top of the unit (breccia B). Breccia A is exposed in the base of the ignimbrite at Cuddia Scauri and consists entirely of plutonic lithic clasts (up to $40 \mathrm{~cm}$ ) and is inferred to correlate with the lowermost bed at the type section (Figure 4). Breccia B is a heterolithic clast-supported, massive lithic breccia (30-50 \% lithic clasts) reaching several metres thickness (Figure 5) and has been seen in the north of the island (near Bagno dell'Acqua, at Cala di Bevira and in a cove north of II 
Porticello; Figure 1). Juvenile clasts $(\sim 30 \mathrm{~cm})$ are generally angular and lithic clasts $(\sim 40 \mathrm{~cm})$ are rounded to subrounded though in more distal exposures the juvenile clasts are also rounded. Most lithic clasts are hydrothermally altered. Both nonvesicular and vesicular juvenile clasts are present in this layer.

Interpretation: The eruption starts with ejection of plutonic blocks, indicating some initial explosion deep in the conduit, recorded as Breccia A where the pyroclastic density current initially carried large numbers of coarse plutonic lithic clasts. Supply (or deposition) of these then waned and an unsteady PDC-forming eruption was established. The current was variably a concentrated, granularfluid based current or a dilute current which welded as the deposit aggraded until the end of the eruption when the deposit abruptly becomes non-welded and the current deposited lithic and pumicious clasts together. In some locations, the final stage of eruption is caldera collapse (Breccia $B$, inset on Figure 4); an interpretation of this breccia as a coarse ignimbrite facies, emplaced hot, is favoured over e.g. fluvial transport (e.g. Mahood \& Hildreth, 1986) because of thermal spalling on lithic clasts, juvenile clasts with 'bread crusts', juvenile clasts moulded around lithic clasts and lack of bomb sags (Figure 5). The thin tuff layer is interpreted as an ash-fall layer which would indicate a break in the deposition from density currents.

The unique vesiculation seen in the Mordomo Formation is unknown but round vesicle shapes may indicate vesicles which have formed after deposition and record ongoing degassing of juvenile particles after primary welding has taken place. 


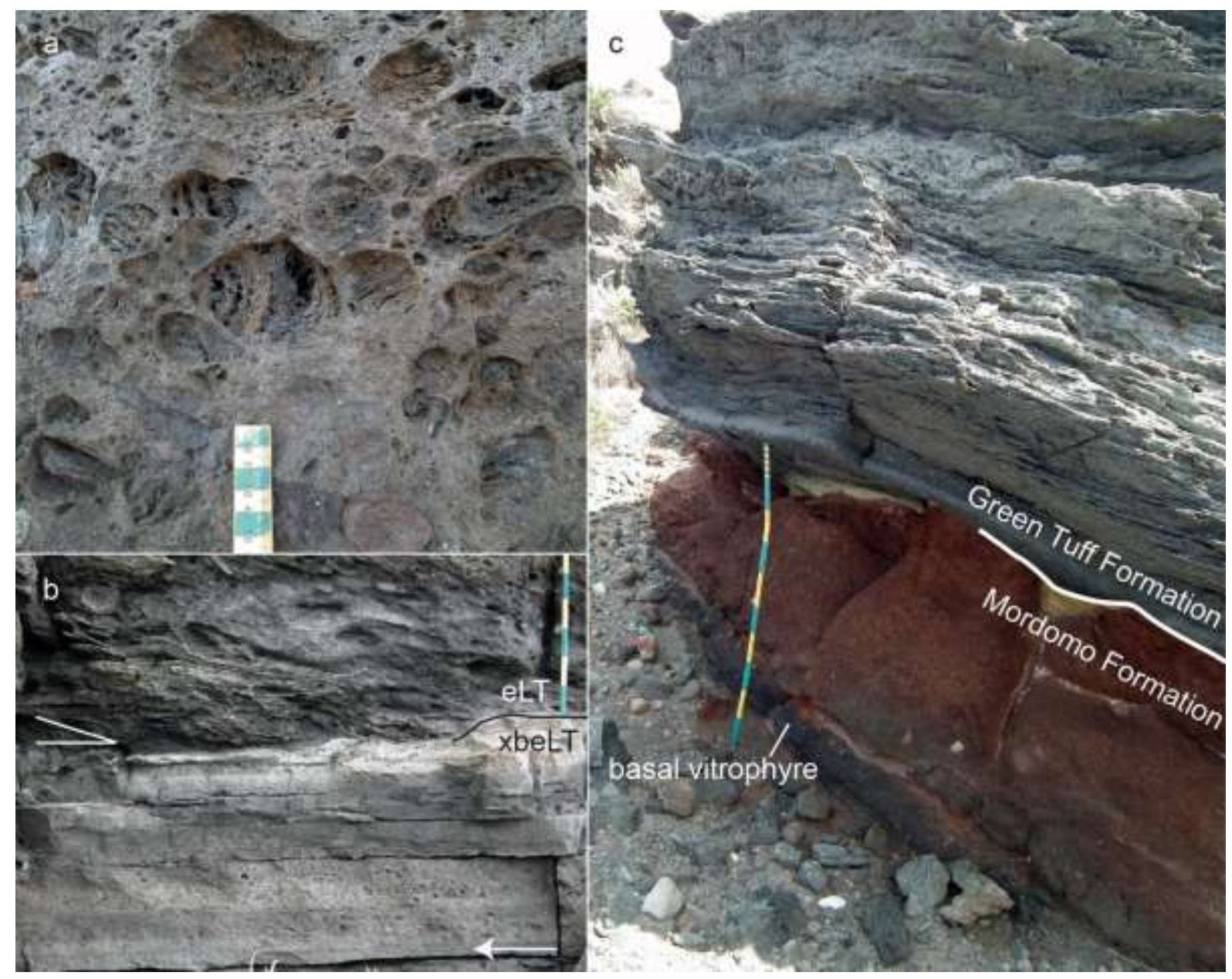

Figure 3. Field photos of the Mordomo Formation. A: Revesiculated juvenile clasts are one of its most characteristic features. Type section. B: Base of Mordomo Formation at 'Roman Road', showing transition from $x b e L T$ to $e L T$ lithofacies. Imbrication and bedding angles are indicated. C: The Mordomo Formation on the south coast of Pantelleria: weathered (red) thin ignimbrite with fresh glass preserved only in the basal vitrophyre (black). Clifftop near Cuddia di Scauri. 


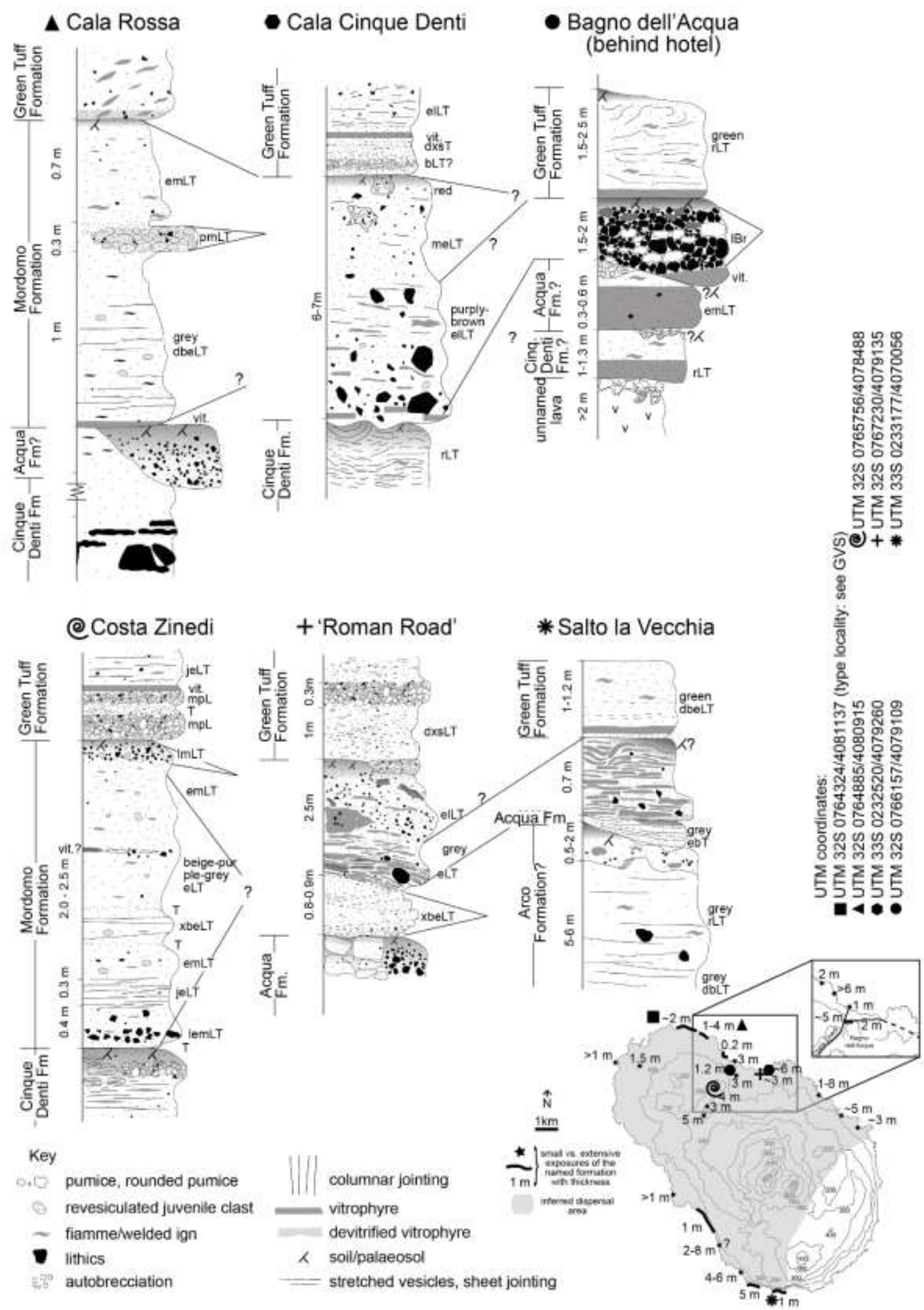

Figure 4. Logs of key sections showing lateral variation in the Mordomo Formation. Note that the formation is very variable and that lithofacies do not normally correlate widely. Some sections contain units not shown here: only units in contact with the Mordomo Formation have been drawn. For type section see GVS. Map 
shows exposures of the (whole) Mordomo Formation on Pantelleria. Inset shows locations and thickness of the heterolithic breccia (Breccia B) at the top of the formation.
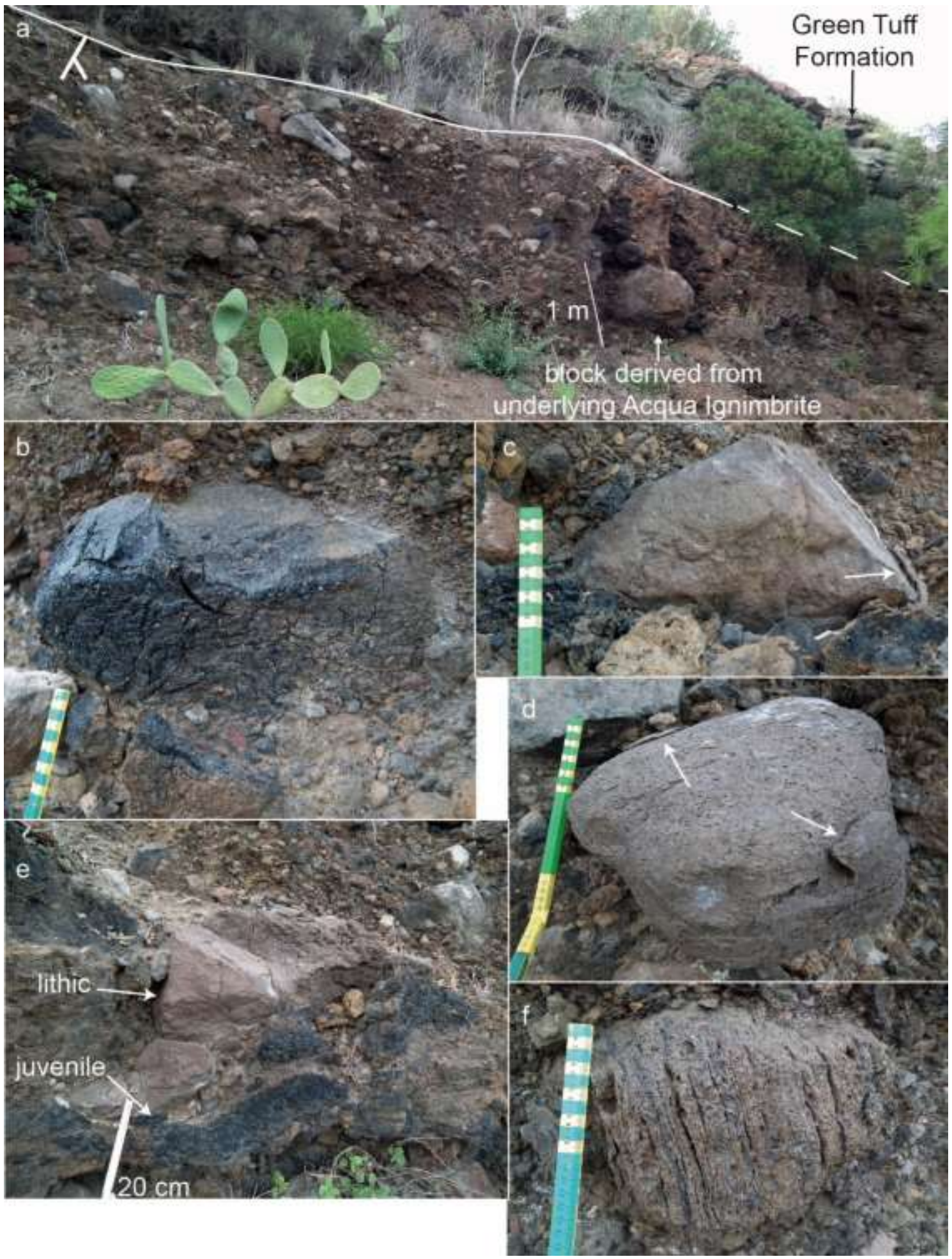

Figure 5. Field photos of the lithic breccia at the top of the Mordomo Formation (breccia B) as seen on a hotel terrace (excavated 2012) above Bagno dell'Acqua (32S0766273/4079150); see Figure 4 for more locations of the breccia. a: Overview and contact with the Green Tuff Formation. No basal contact of the breccia has been seen; its thickness is estimated at a minimum value of $\sim 5 \mathrm{~m}$. b: Juvenile black clast with bread crust indicating hot emplacement. C, d: Lithic clasts with thermally spalled rinds indicating hot emplacement. E: Lithic clast moulded into juvenile clast indicating hot emplacement and low viscosity. F: Typical striped juvenile clast of the Mordomo Formation. 


\subsection{Acqua Formation}

\subsubsection{Definition}

The rhyolitic Acqua Formation (new name) consists of a welded ignimbrite and local lithic breccia. It is capped by a weathering horizon at the top and overlies the weathering horizon of an older formation (Cinque Denti Formation). It is overlain by the Mordomo Formation.

The type locality is in the north of the island in a roadcut at Bagno dell'Acqua, the caldera lake (Figure 1), on the road from Pantelleria town to Bugeber.

\subsubsection{Lithofacies}

Description: At the type section, the lower three quarters ( $\sim 7 \mathrm{~m}$ ) of the Acqua Formation consists of a rheomorphic ignimbrite with lithic-rich lenses at the base and laterally impersistent faint beds throughout (log: Figure 2). It is pink-grey, crystal-rich (average feldspar: $5 \mathrm{~mm}$ ) and poorly sorted with subhorizontal cavities and fiamme. Rare lithic clasts of 1-3 cm are commonly clustered together. Light grey fiamme of $\sim 1 \mathrm{~m}$ length are present.

At the top of the ignimbrite there is a sharp contact (no soil) with a 3-5 m thick lithic breccia transitional into scoria agglomerate. The breccia has a flat, horizontal top but its lower contact (i.e. with the top of the ignimbrite) undulates on a metre-scale. It consists of variably matrix or clastsupported blocks and spatter bombs of a maximum diameter of $12 \mathrm{~cm}$ (Figure 6). Proportions of juvenile to accidental and accessory clasts and the amount of ash matrix vary laterally and vertically. Generally the lithic content increases toward the top. Bedding and imbrication have not been seen (though imbrication may not be expected due to the orientation of the exposure perpendicular to the current direction). Juvenile clasts are commonly draped over accidental and accessory clasts or sintered to other juvenile clasts. Where there is a large concentration of juvenile clasts the sintering has progressed so far that individual clast outlines are difficult to detect. Some juvenile clasts have chilled rinds (Figure 6). Juvenile clasts are not ropy or spindle-like but are approximately equant or oval. They are moderately vesicular. Near the top of the horizon the juvenile clasts are commonly black and glassy i.e. an equivalent of a top vitrophyre. Accidental and accessory clasts are rounded whereas juvenile clasts have rough surfaces. Thermally spalled rinds can be seen on accidental and accessory clasts (Figure 6). The breccia is capped by a well-developed orange weathering horizon (palaeosol).

The Acqua Formation has been correlated, based on its stratigraphic position and its lithic breccia, over much of the island except for the east coast (Figure 7). In some places it is strongly rheomorphic (Figure 8), usually where it is thickest, whereas in other places it is thin and appears foliated and with sheared gas cavities (Figure 8). The thickness of the formation varies markedly (from $0.2 \mathrm{~m}$ to 
$10 \mathrm{~m}$ ) with both the thickest ignimbrite and thickest lithic breccia exposed in the type locality (Bagno dell'Acqua). It is absent at several of the studied localities such as the Costa di Zinedi scarp (at 180 m.a.s.l.) and Cala della Pozzolana (see Figure 1 for locations).

Interpretation: The lithic-rich lenses at the base of the ignimbrite may indicate an increased supply of lithics to the current early in the eruption or a flow-boundary zone in which turbulence and traction were briefly suppressed. Most of the ignimbrite would have been deposited from a more uniform high-concentration granular flow, though the faint bedding may indicate some unsteadiness at the flow-boundary zone. At up to $4 \mathrm{~m}$, the lithic breccia is the thickest one found on Pantelleria (most are $<2 \mathrm{~m}$ ) so would constitute a potential candidate for the collapse events proposed in the literature (e.g. Mahood \& Hildreth, 1986). Scoria agglomerates, like lithic breccias, are ignimbrite deposits indicative of large eruptions and are potential evidence for water in the vent (Mellors \& Sparks, 1991).

The thickness of the Acqua Formation is $\sim 4 \mathrm{~m}$ at most locations (Figure 7 ) with the exception of the type locality where it is $10 \mathrm{~m}$ thick (currently located on a topographic caldera rim). Such a thickness may represent an intracaldera facies and thus the caldera wall at the time of the Acqua eruption extended closer to the sea but is now buried.

The formation's absence in eastern and western locations (Figure 7) indicates that the current was not able to overtop tall topographic barriers or did not deposit here. 


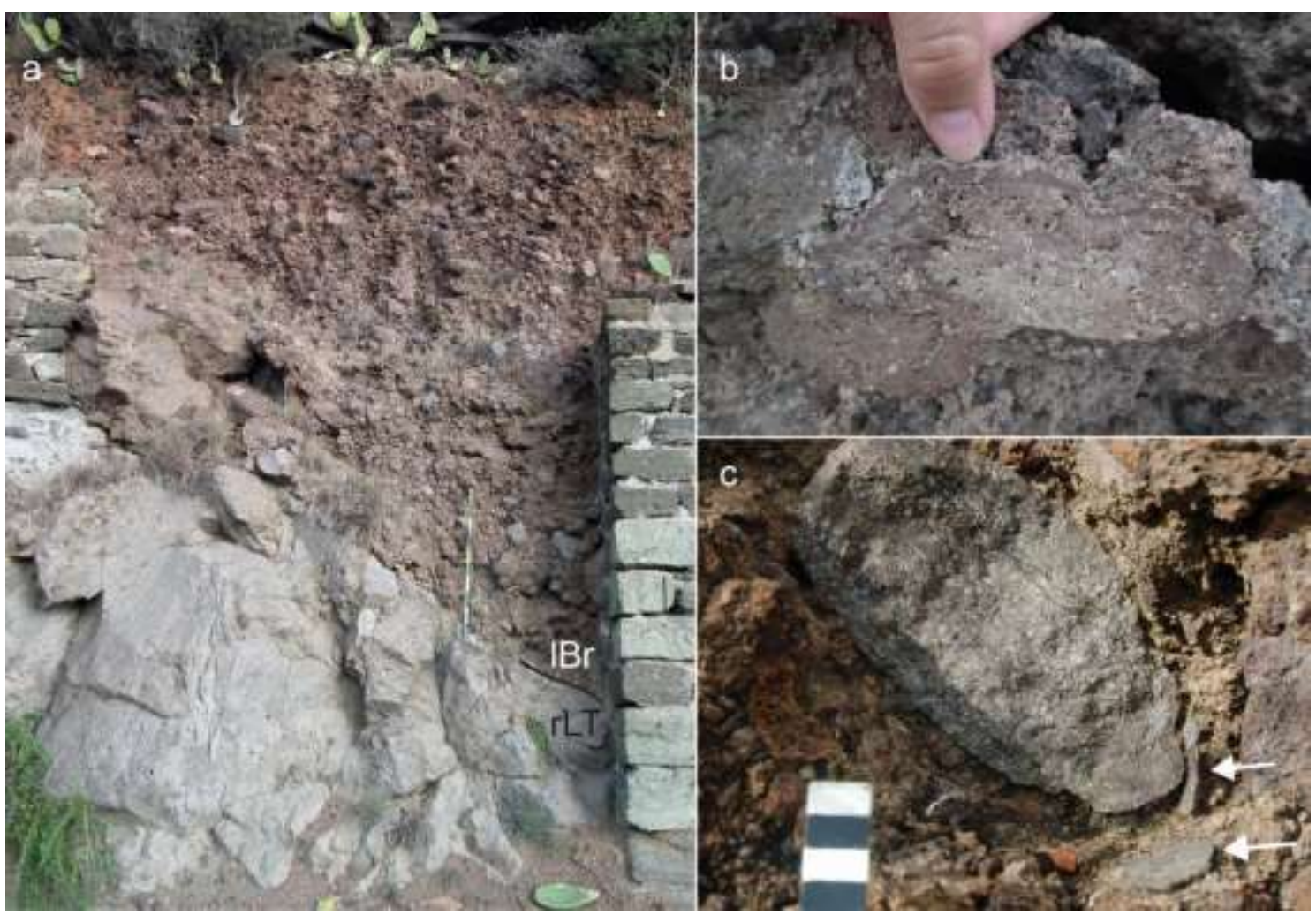

Figure 6. A: Typical appearance of the Acqua Formation in the north of Pantelleria. It is capped by a lithic breccia as thick as $\sim 4 \mathrm{~m}$. Note many different clast types and varying amounts of juvenile, accessory and accidental clasts. Metre-rule for scale. B: Cross section through crystal-rich juvenile clast (in the breccia) with chilled rind. C: Lithic clast (in the breccia) with thermally spalled flakes indicative of hot emplacement. Arrows point to some of the broken-off flakes. Ruler shows cm division. 


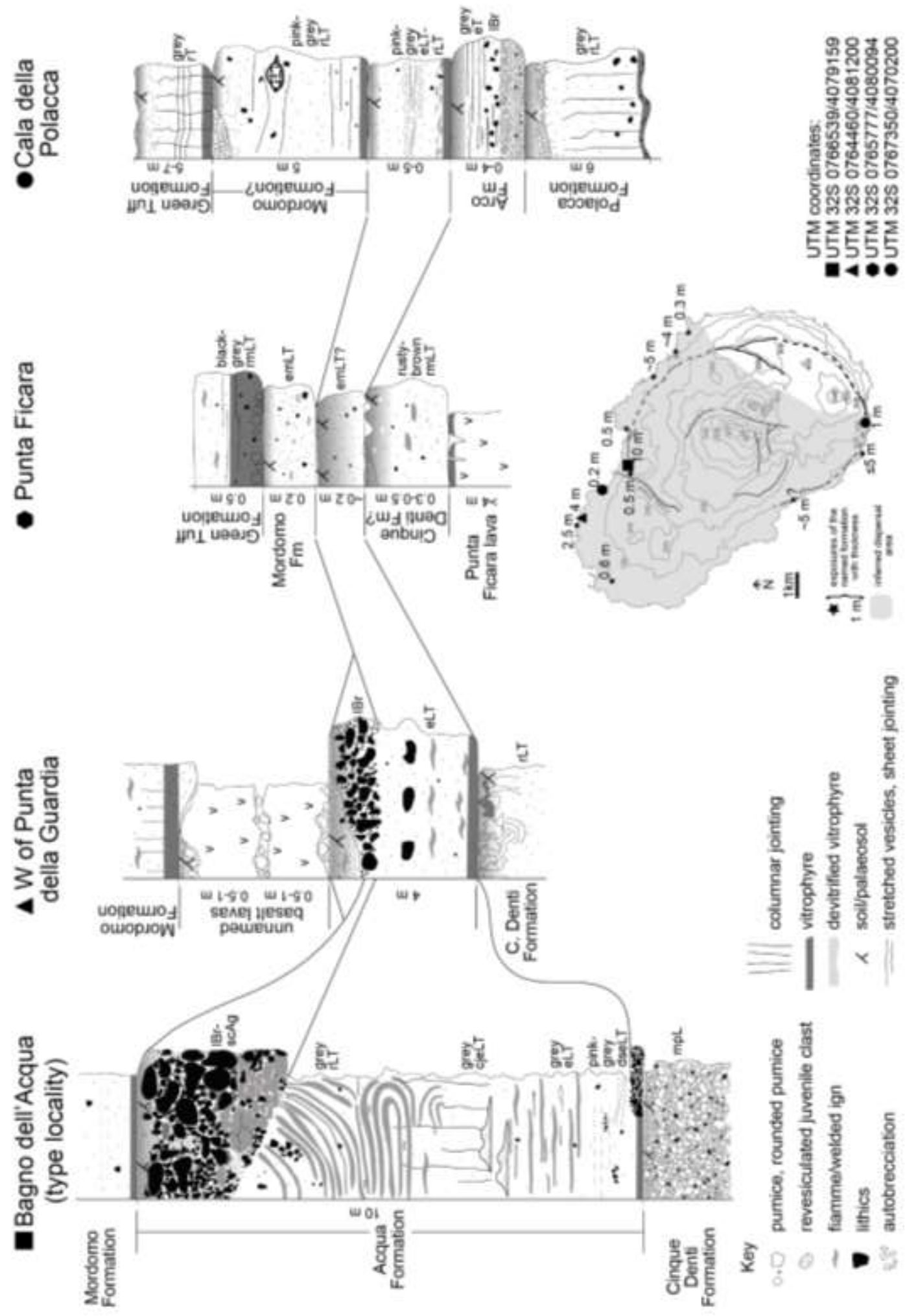

Figure 7. Logs of key sections on Pantelleria showing lateral variation in the Acqua Formation compared to the type section (column 1). Some sections contain units not shown here: only units in contact with the Acqua Formation have been drawn. Map shows occurrences of the Acqua Formation on Pantelleria. The Formation is thought not to have overtopped the high areas in the east while the low areas in the west do not expose the relevant stratigraphic level but are thought to have been inundated by the density current. 


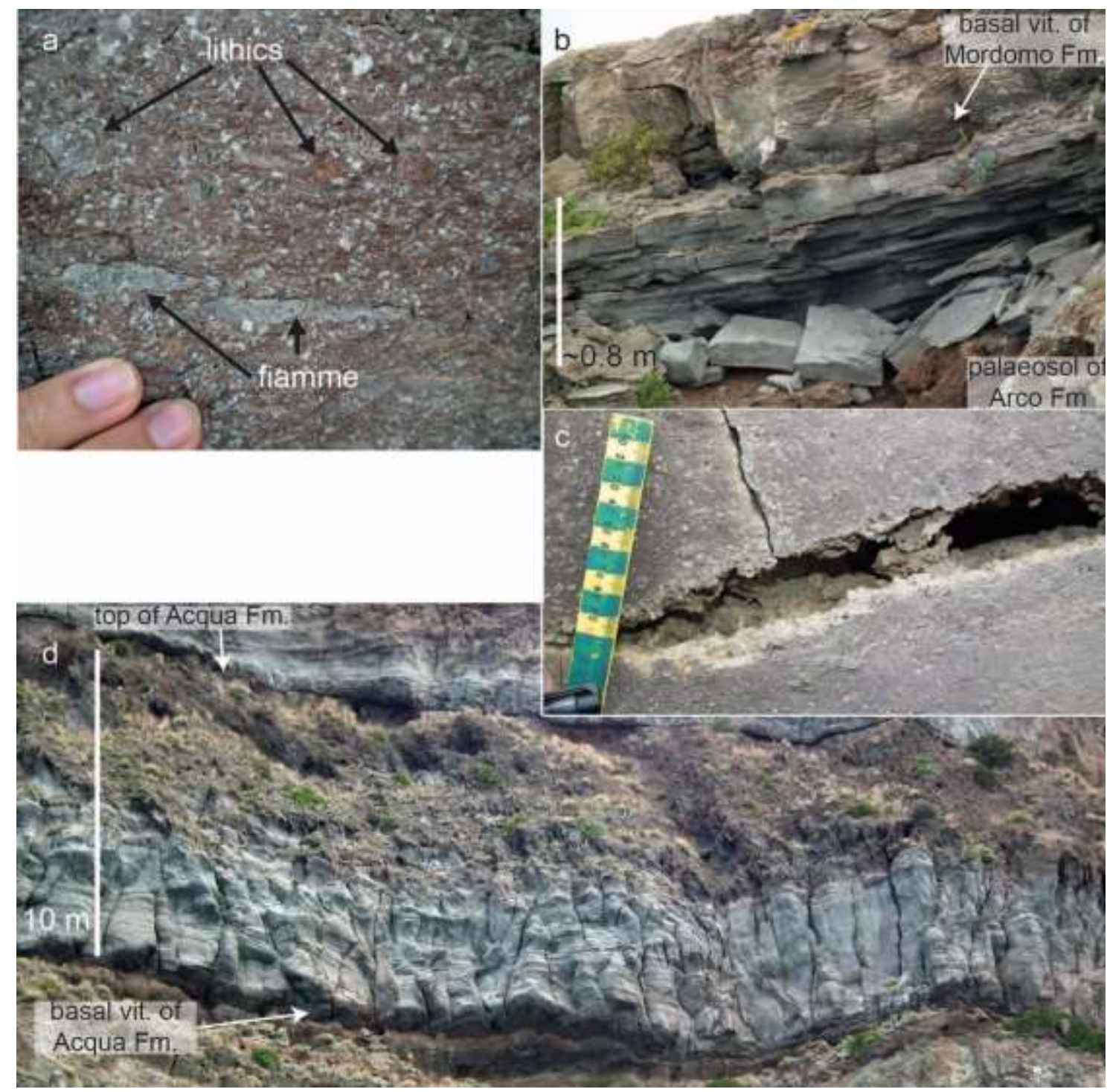

Figure 8. A: Close-up of Acqua ignimbrite showing large proportion of crystals (seen in caldera scarp at type section). Also shown are fiamme (grey) and lithics (brown, red, grey). B: At Salto La Vecchia (on a palaeo-high) the Acqua Formation appears bedded and is characterised by gas blisters and sheared vesicles (C). Note that the lithic breccia seen at the type locality is not seen along the south coast. C: Close-up of sheared vesicle seen at Salto La Vecchia. Also note that crystals are much smaller and less abundant than in the north (A). D: In this section on the south coast (Cala Di Licata) the formation displays a strongly brecciated rheomorphic top (top half).

\subsection{Cinque Denti Formation}

\subsubsection{Definition}

The trachytic-rhyolitic Cinque Denti Formation (new name) is here defined as (i) the Cinque Denti Ignimbrite and (ii) the Bagno member, a subplinian pumice-fall deposit overlying the ignimbrite, best exposed at the Bagno dell'Acqua caldera lake. Both are interpreted as a single eruption-unit due to being bounded by weathering horizons at the top (in the top part of the pumice fall) and base. There is no weathering horizon in the top of the ignimbrite. 
The type locality for the Cinque Denti Formation is on the north coast of Pantelleria at Cala Cinque Denti (Figure 1). The formation is exposed on both sides of the bay; the lower part can be accessed on the $\mathrm{W}$ side of the bay; the upper part can be accessed on the $\mathrm{E}$ side. Another key section is the road section at Bagno dell'Acqua (see type locality of Acqua Formation).

At the type section, the Cinque Denti Formation is underlain by the Capre Formation. It is overlain by the Mordomo Formation on the W side of the bay and a sliver of Acqua Formation on the $E$ side of the bay.

\subsubsection{Lithofacies}

At the type section the Cinque Denti Formation has a maximum thickness of $~ 7-8 \mathrm{~m}$ and comprises a pumice-fall deposit and welded ignimbrite (log: Figure 2).

\section{Cinque Denti Ignimbrite}

Description: The Cinque Denti Ignimbrite (CDI) makes up the lower three quarters of the Cinque Denti Formation (log: Figure 2). At the base of the ignimbrite there are abundant lithic lapilli and blocks (maximum length: $40 \mathrm{~cm}$, average: $7 \mathrm{~cm}$ ) set in a eutaxitic, locally glassy, crystal-rich matrix (feldspars average $8 \mathrm{~mm}$ length; Figure 9). The lithic lapilli are mostly subrounded and of various types but are predominantly very fine-grained aphyric or porphyritic clasts. The bulk of the ignimbrite is grey, poorly sorted, matrix-supported, crystal-rich and lithic-poor with subtle fiamme. At the top of the ignimbrite there are $\mathrm{dm}$ to $\mathrm{m}$-scale mostly open folds (e.g. Figure 9). The uppermost 0.2-2 $\mathrm{m}$ are heavily cracked and broken into small pieces indicating autobrecciation.

The Cinque Denti Formation is mainly exposed in the northern half of Pantelleria (Figure 10). It varies in thickness, amount of accidental/accessory clasts, extent of rheomorphism and presence or absence of the pumice fall when comparing different exposures (Figure 10). It can be recognised by its stratigraphic position, pumice fall on top (where present), strongly folded and autobrecciated top and large feldspar crystals.

Interpretation: This thick massive deposit may indicate deposition from a steady concentrated current. Due to its thickness it was hot long enough to deform and fold rheomorphically. The Cinque Denti Ignimbrite is a rather enigmatic unit due to its pronounced thickness variations and seemingly limited dispersal (Figure 10). Its thickness of $>10 \mathrm{~m}$ in some places qualifies it as potential calderaforming unit but in some exposures it is only $\sim 2 \mathrm{~m}$ thick and, furthermore, it is not found over the entire island (Figure 10).

Both the ignimbrite and pumice fall have dominantly northerly dispersals (Figure 10), possibly due to exposure availability: exposures in north-western sea cliffs only expose the Green Tuff Formation 
and younger eruption-units, whereas the eastern and southern sea cliffs commonly rise to $>100 \mathrm{~m}$ and the relevant stratigraphic interval is not accessible. When tracing eruption-units (with binoculars, by boat) southward along the cliff from Punta dell'Arco, the Cinque Denti Formation does not seem to appear in the sea cliffs and the Green Tuff Formation is seen to overlie the Arco Formation directly. This may indicate that at the time of the Cinque Denti eruption (and, by extension, the Acqua and Mordomo eruptions) this eastern part of the island formed a palaeotopographic high that the pyroclastic density current(s) did not surmount or, if they did, they did not deposit here. It would also require that the pumice fall was wind-blown toward the north.

\section{Bagno Member}

Description: This 0.6-1 m thick layer (Figure 9) consists of white to yellow to orange clast-supported well-sorted pumice and subordinate black glassy lithic lapilli. Individual pumice clasts are 1-3 cm long and lithic lapilli are generally $0.5 \mathrm{~cm}$ long. Bedding is subtle and beds cannot be traced between different exposures. Free crystals of clear feldspar are common. The deposit has a relatively flat top but very irregular base due to the underlying autobrecciated ignimbrite. The colour grades from yellow-white at the base to bright orange-red at the top. The deposit is not welded.

Interpretation: The Bagno Member of the Cinque Denti Formation is interpreted as a non-welded fallout deposit based on being clast-supported, well sorted and juvenile clasts being much bigger than accidental/accessory clasts. The bright orange top of this layer is interpreted as due to intense baking of a weathering horizon by the overlying welded ignimbrite.

There is no indication of a weathering horizon in the ignimbrite thus the pumice fall is considered part of the same eruption and it is expected that the time elapsed between them is short (hours to days). However, the pumice is not fused to the ignimbrite which might be expected if it had fallen onto the still hot deposit. Due to their low viscosity and glass transition temperature, pantellerite magmas are hot enough to weld and deform for several weeks (Di Genova et al., 2013) thus this is inferred to be the minimum time gap between the eruption of the ignimbrite and the pumice fall.

Considering the exposures of where the Cinque Denti pumice fall has been reliably identified (Figure 10 ) it is difficult to get a good picture of its dispersal because very few locations are exposed and the surface area of Pantelleria is small $\left(83 \mathrm{~km}^{2}\right)$. It may be assumed that a large part of the eruption products were deposited onto the sea. While the dispersal of the pumice fall cannot be mapped fully it seems safe to assume it covers an area of less than $500 \mathrm{~km}^{2}$ but more than $5 \mathrm{~km}^{2}$ and thus can be classed as subplinian sensu Walker (1973). 


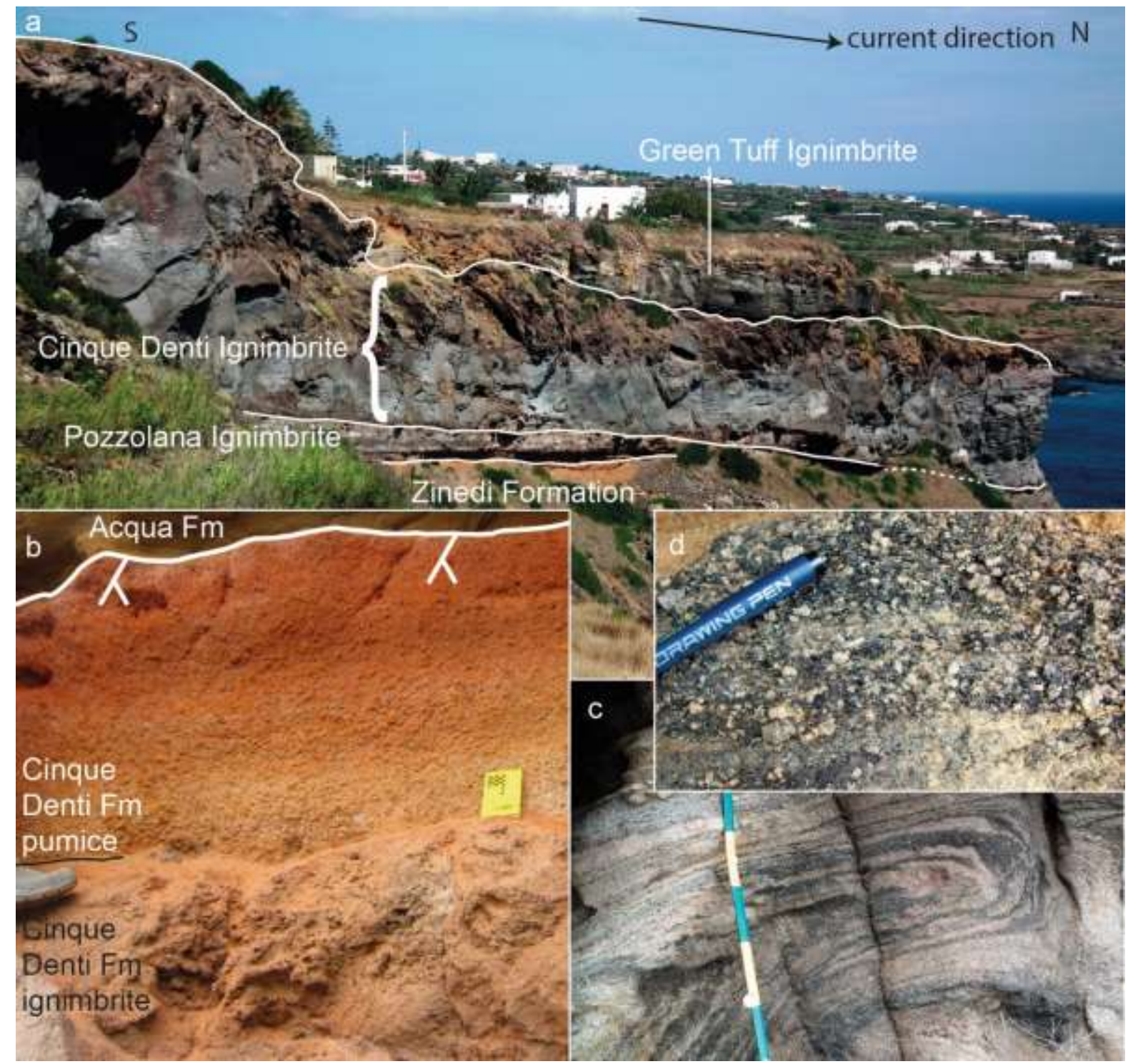

Figure 9. Characteristics of the Cinque Denti Formation. A: The Cinque Denti Ignimbrite at Cala della Pozzolana. Note autobrecciated top (dark) and lateral thickness change (from $\sim 15$ to $\sim 8 \mathrm{~m}$ ). B: Non-welded pumice fall on top of ignimbrite at Cala Cinque Denti type locality (notebook rests on contact between ignimbrite and pumice-fall deposit). Orange colour resulted from baking of palaeosol by a later eruption (Acqua Formation). Fresh pumice clasts are white. C: Folded glassy fiamme near top of ignimbrite on Costa Zinedi scarp indicating rheomorphic flow. D: Representative close-up of glassy top vitrophyre in Cinque Denti Ignimbrite showing typical large feldspar crystals (white). This ignimbrite contains the biggest crystals and largest abundance of feldspar of all ignimbrites on Pantelleria. 


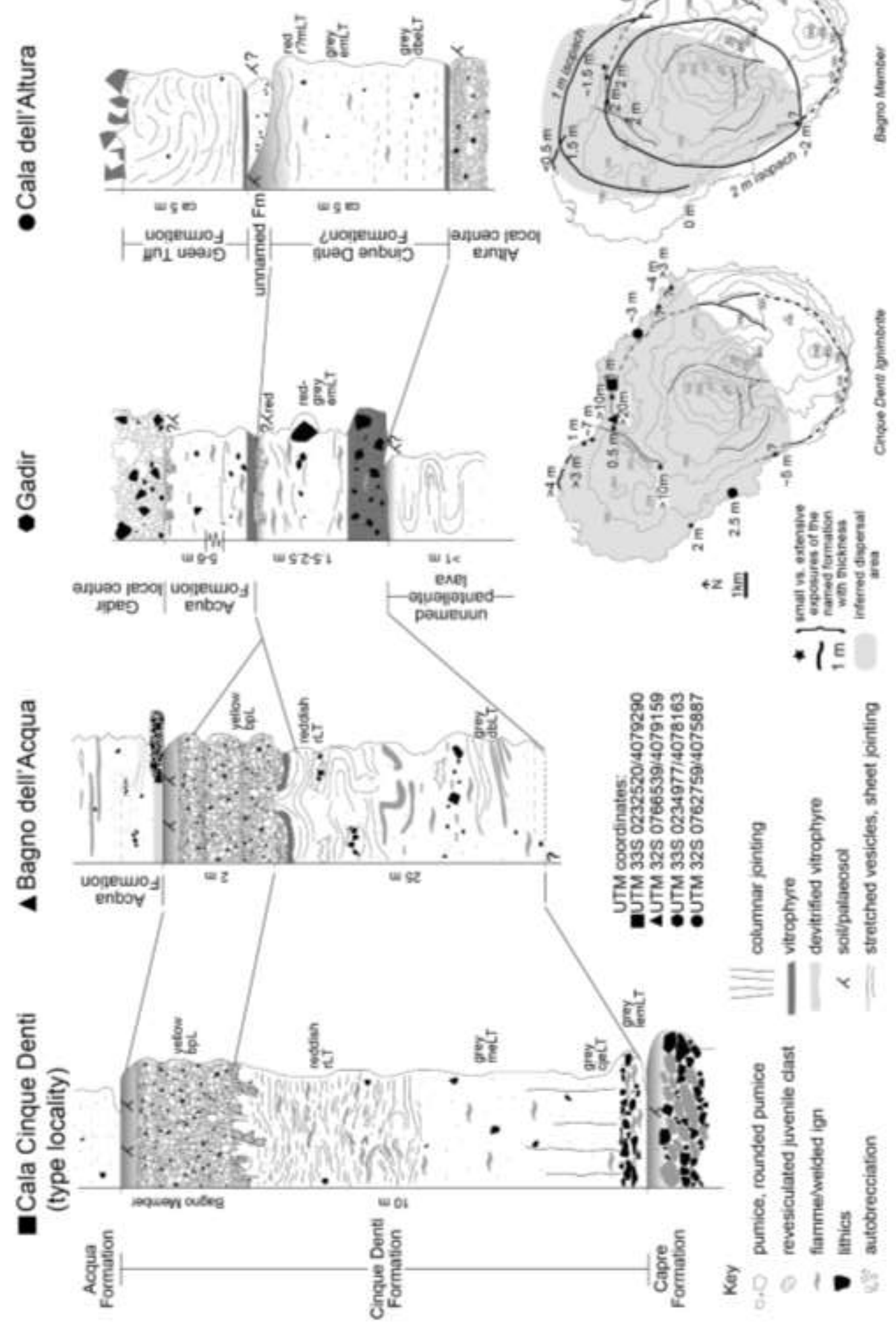

Figure 10. Selection of logs of the Cinque Denti Formation from around the island illustrating lateral variability compared to the type section (column 1). Note absence of pumice in many locations. Sections contain units not shown here: only units in contact with the Cinque Denti Formation have been drawn. The maps show exposures of the Cinque Denti Formation ignimbrite and pumice fall and inferred maximum aerial distribution. Correlation to the south coast is uncertain. While largely inaccessible, the density current is not thought to have overtopped the high areas in the east of the island. Crude isopach maps for the 1 and $2 \mathrm{~m}$ contour lines are shown and from these is can be inferred that the pumice must have been eroded in some coastal locations (Gadir, Cala Dell'Altura). 


\subsection{Capre Formation}

\subsubsection{Definition}

The trachytic Capre Formation (new name) consists of a thin nonwelded pumice fall and thick welded lithic-rich ignimbrite (log: Figure 2). It is capped by a weathering horizon at the top and overlies the weathering horizon of an older formation (Arco Formation). It is overlain by the Cinque Denti Formation. Its type locality is at Cala delle Capre on the south coast of the island (Figure 1) which is only accessible by boat. Its top is also exposed at Cala Cinque Denti on the north coast (see Cinque Denti Formation type section).

\subsubsection{Lithofacies}

At the type section the Capre Formation has a maximum thickness of $\sim 14 \mathrm{~m}$ and comprises a pumice-fall deposit and welded ignimbrite (log: Figure 2).

\section{Capre Formation pumice-fall deposit}

Description: The basal $0.3 \mathrm{~m}$ at the type locality consist of beige clast-supported well-sorted angular pumice lapilli with subordinate (<10 vol\%) lithic lapilli. Pumice lapilli are typically $1.5 \mathrm{~cm}$ long and lithic lapilli $<1 \mathrm{~cm}$. The horizon is not welded and not bedded (Figure 11).

Interpretation: It is interpreted as a non-welded pumice-fall deposit based on being clast-supported, well sorted and juvenile clasts being angular and much bigger than accidental/accessory clasts.

\section{Capre Formation ignimbrite}

Description: Overlying the pumice-fall deposit there is a lens of variably matrix and clast-supported rounded pumice and lithic clasts, both of which are finer than in the pumice fall (Figure 11). The lens includes cross-bedded areas and grades vertically and laterally into matrix-supported lithic-rich eutaxitic lapilli-tuff (leLT). Near the base, the ignimbrite contains a striking amount of black fiamme (Figure 11), otherwise is it brown in colour. The lithic content ( $M L=9 \mathrm{~cm}$ at the base) may be as high as 50 vol\% but lithic clasts are still matrix-supported. Higher up in the unit some clasts are $2 \mathrm{~m}$ long but most are $<1 \mathrm{~m}$. Clasts are of many different types (heterolithic) with dominantly very finegrained or glassy aphyric lithologies and hydrothermally altered clasts. Fist-size coarse-grained crystalline clasts ('syenites') have been recorded. Some lithic clasts show curvilinear cracks inferred to record thermal spalling. No impact structures have been seen. While the top half of the deposit cannot be accessed, it looks massive from a distance with lithic clasts becoming scarcer up-section.

The ignimbrite has been seen from a distance in several south coast cliff faces, in most places with a thin fallout deposit underneath. It can be recognised by its stratigraphic position above the Arco Formation (see next section). It has been correlated with the lithic-rich scoria agglomerate 
underlying the Cinque Denti Formation at Cala Cinque Denti (north coast) based on palaeomagnetic (Speranza et al., 2012) and radioisotopic data (Rotolo et al., 2013). Here, its base is not exposed and therefore the pumice fall has not been seen. Like the Cinque Denti Formation, the Capre Formation is characterised by pronounced thickness variations when traced across the island (1-2 $\mathrm{m}$ in most sections; Figure 12). It is predominantly seen in central locations and is absent from the east and west of the island (Figure 12).

Interpretation: The rounded pumice clasts are interpreted as having been picked up by the pyroclastic density current from the underlying pumice-fall deposit and having undergone rounding during transport. They would have cooled the current, thus preventing welding. The lithic-rich parts containing plutonic lithic fragments may indicate a phase of caldera collapse at the eruption climax. The black fiamme are likely to be an equivalent of a basal vitrophyre and scarce lithic clasts toward the top mean that the supply of lithic clasts waned during the eruption. From its unusual thickness (>10 m) we may infer that the type section (Cala Delle Capre) may have been inboard of the caldera wall at the time of the Capre eruption (Figure 12). The lack of deposits in eastern and western locations may mean that the current was unable to overtop some of the topographic palaeo-highs in the west and east of the island (Figure 12). 


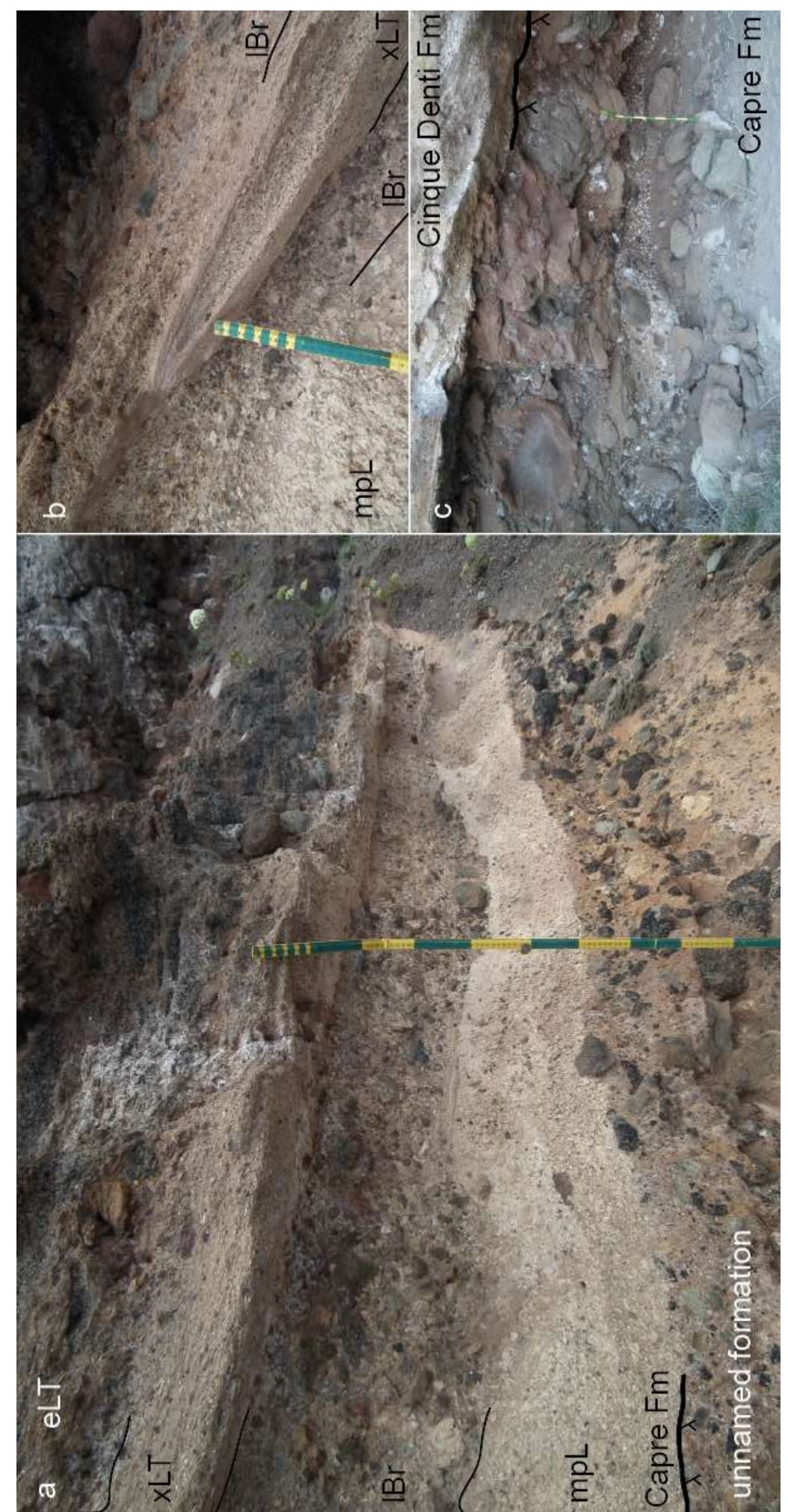

Figure 11. Field characteristics of the Capre Formation. A: Base of the formation at the type section. Pumicefall deposit ( $\mathrm{mpL}$ ) overlies the palaeosol of an undefined formation (boundary marked by black line). This is in turn overlain by the ignimbrite which transitions upward from nonwelded (beige) to welded (black). B: Detail of the base of the nonwelded ignimbrite, showing cross-bedding. C: Top of the Capre Formation at Cala Cinque Denti. The contact with the overlying Cinque Denti Formation is marked by the black line. 
- Cala delle Capre (type locality)

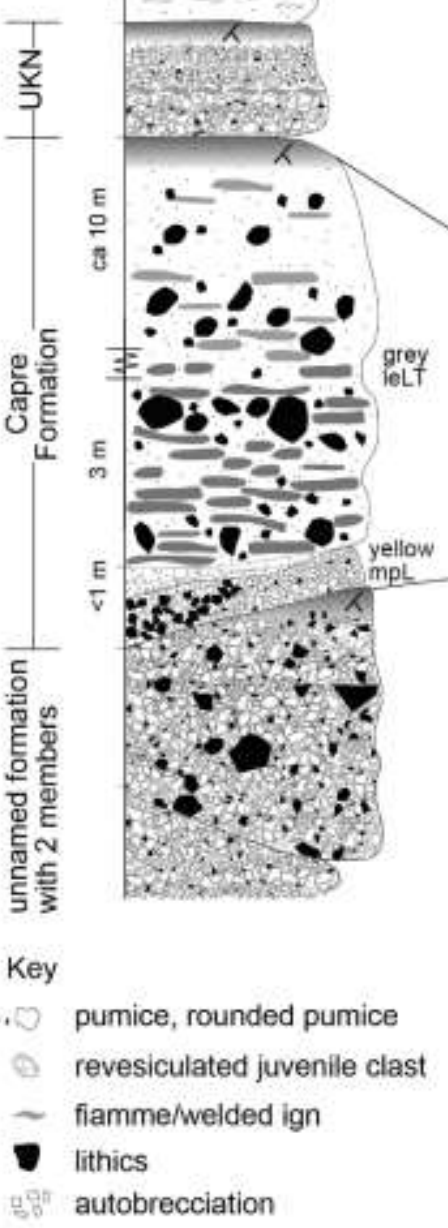

UTM coordinates:

UTM 32 S $0766031 / 4071835$

A UTM 335 0232520/4079290

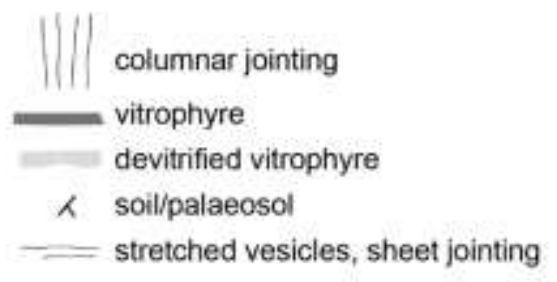

A Cala

Cinque Denti
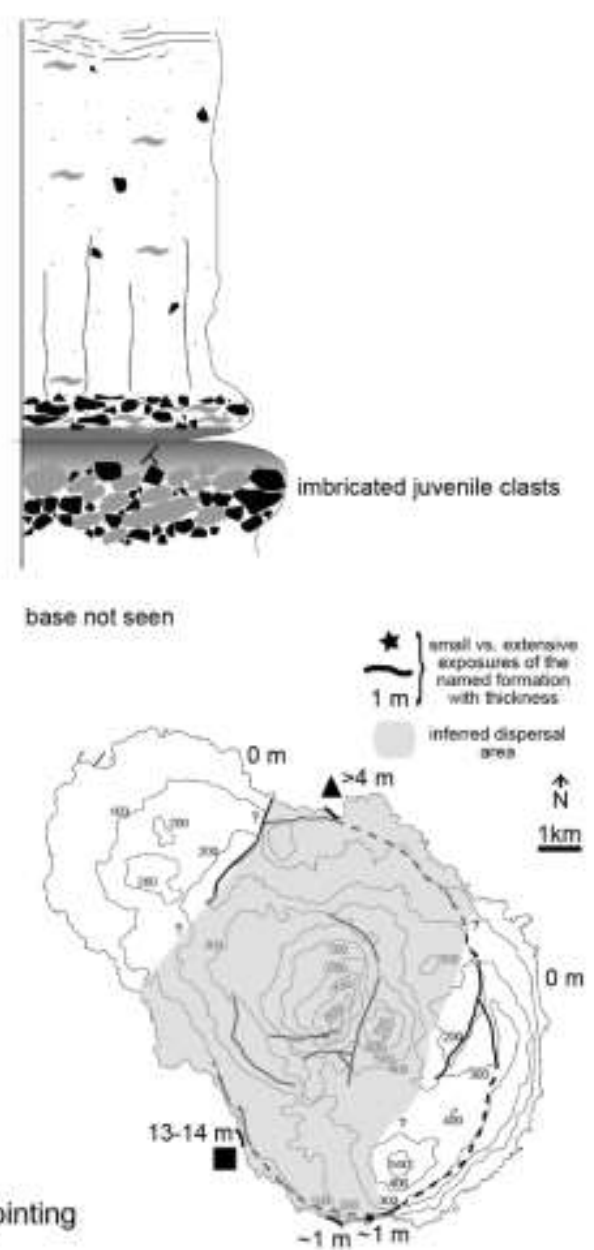

Figure 12. Logs of the Capre Formation illustrating lateral variability (only two locations are accessible). UKN = unknown nonwelded pumice deposit. Sections contain units not shown here: only units in contact with the Capre Formation have been drawn (see also Figure A.1). Map shows exposures of the Capre Formation and inferred dispersal area. The density current seems not to have overtopped high areas to the east and west of the caldera.

\subsection{Arco Formation}

\subsubsection{Definition}

The trachytic-rhyolitic Arco Formation (new name) consists of a fallout deposit and overlying welded ignimbrite. It is bounded by weathering horizons at the top and base (in the top of the Polacca Formation) and is interpreted as an eruption-unit. It is overlain by the Capre Formation.

The type area for this formation is on the east coast of Pantelleria, $500 \mathrm{~m}$ south of Punta dell'Arco, a famous Pantescan landmark, after which it is named (Figure 1). This is the most complete section for this unit but is only accessible by boat. Much of the ignimbrite is also accessible at Salto La Vecchia. 


\subsubsection{Lithofacies}

At the type section the Arco Formation has a maximum thickness of $20 \mathrm{~m}$ and comprises a pumicefall deposit and welded ignimbrite (log: Figure 2).

\section{Arco Formation pumice-fall deposit}

Description: Pumice makes up the lower $12 \mathrm{~m}$ of the formation and consists of clast-supported, angular yellow pumice and subordinate lithic lapilli (Figure 13). The largest pumice lapilli ( $\leq 13 \mathrm{~cm}$ ) are larger than the lithic lapilli, which consist predominantly of hydrothermally altered and black glassy obsidian. No bedding is seen. The nonwelded pumice grades upward into the overlying flattened and welded pumice lapilli and angular non-flattened lithic lapilli (Figure 13). Toward the top the pumice lapilli become more and more flattened and glassy. Outlines of individual clasts can be seen but the pore space (both between and within pumice clasts) is much lower compared to the massive pumice lapilli lithofacies. No bedding and no imbrication of fiamme have been seen. There is a sharp contact with the overlying ignimbrite.

The pumice disappears under water toward the north but can be traced southward for $\sim 1 \mathrm{~km}$. Its thickness decreases slightly and the welded part is thinner in relation to the non-welded part. It is only $0.5 \mathrm{~m}$ thick in the southern exposures (compared with $\sim 12 \mathrm{~m}$ at the type locality; Figure 14).

Interpretation: The massive pumice lapilli and massive eutaxitic pumice lapilli lithofacies are interpreted as a pumice-fall deposit on the basis of being clast-supported and juvenile components being angular and larger than accidental/accessory components. The absence of bedding may indicate a steady eruption column at the start of the eruption. Welding begins in the upper third of the deposit and increases upward through the succession, possibly indicating a higher eruption temperature, greater rate of deposition (and therefore mass flux) or a shift in the wind direction. Given the small size of the island $\left(83 \mathrm{~km}^{2}\right)$ and the limited exposure of the pumice fall, no reliable isopach map can be drawn, but it is likely that its dispersal is between $5 \mathrm{~km}^{2}$ and $500 \mathrm{~km}^{2}$ and is thus classified as subplinian sensu Walker (1973).The lateral thinning to the south of both the pumice layer thickness and the welded part within it indicates that the vent was on the eastern side of the island, possibly on the nearby caldera rim.

\section{Arco Formation Ignimbrite}

Description: The Arco Ignimbrite is a $8 \mathrm{~m}$ thick diffusely cross-bedded eutaxitic lapilli-tuff. It is reddish brown with beds 2-10 cm thick (Figure 13). Bedding, grain size and colour are correlated: coarser beds are red and tend to stand prominent from the rock face; finer beds are grey or brown and tend to recess. Individual beds can be traced for several metres, splaying of beds is common and 
beds are generally low-angle cross-bedded. $3-5 \mathrm{~cm}$ long fiamme occur in a fine-grained crystal-rich (feldspars of 5-8 mm) matrix and are locally imbricated. Rare lithic lapilli are equant, angular and $\leq 5 \mathrm{~cm}$ long. The ignimbrite can be traced southward for $\sim 1 \mathrm{~km}$ where it disappears from the cliff section. To the north it disappears under water between Punta Dell'Arco and the type section. Its thickness varies little laterally, although it is unclear whether this is due to post-depositional erosion or whether it is a primary feature because the majority of the sea cliff cannot be studied up close (Arco Formation appears gradually higher in the cliff when traced southward).

The Arco Formation has been correlated across the southern coast of Pantelleria based on its stratigraphic position, bedded appearance and the pumice fall at the base (Figure 14; Figure 15). The formation is only exposed in eastern and southern areas of Pantelleria (Figure 14) due to the young age of rocks in the north-western lobe of the island.

The Arco Ignimbrite locally appears less bedded in the southern exposures compared to the type locality (Figure 14; Figure 15). At Cala della Polacca breccia lenses occur near the base of the ignimbrite (Figure 15). In these, clasts $(\mathrm{ML}=11 \mathrm{~cm}$ ) are of many different types (i.e. heterolithic) but dominantly hydrothermally altered clasts.

The Arco Ignimbrite at Salto La Vecchia varies between being massive, diffuse-bedded and rheomorphic (meLT, dbeLT, rheolLT). In contrast, neither the massive nor the rheomorphic lithofacies are seen at the type section, demonstrating the strong lateral variation in these eruptionunits (Figure 15).

Interpretation: The ignimbrite is interpreted to be the deposit of an unsteady dilute current due to its thin beds, bedding and lack of lithic clasts. Unsteadiness at the flow-boundary zone can result from whole-current fluctuations (e.g. clasts supplied to the current) or local fluctuations from e.g. turbulent eddies (Branney \& Kokelaar, 2002). 


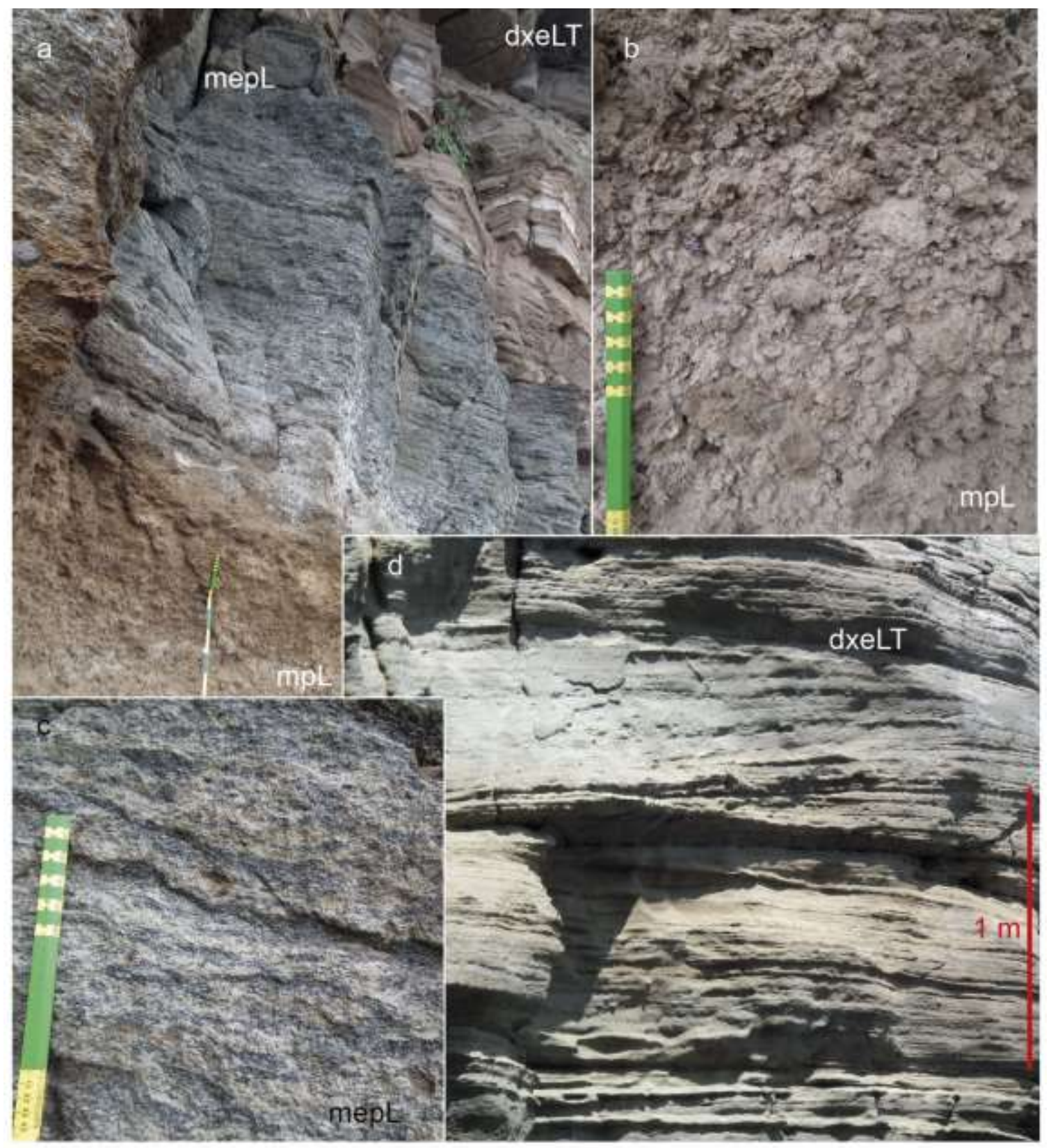

Figure 13. Photos of the Arco Formation at the type section. A: Transition from non-welded base (yellow-beige $\mathrm{mpL}$ ) to welded top (grey-black mepL) in pumice-fall deposit. B: Close-up of non-welded pumice facies. C: Close-up of welded pumice facies D: Diffusely (low-angle) cross-bedded welded Arco Ignimbrite. 


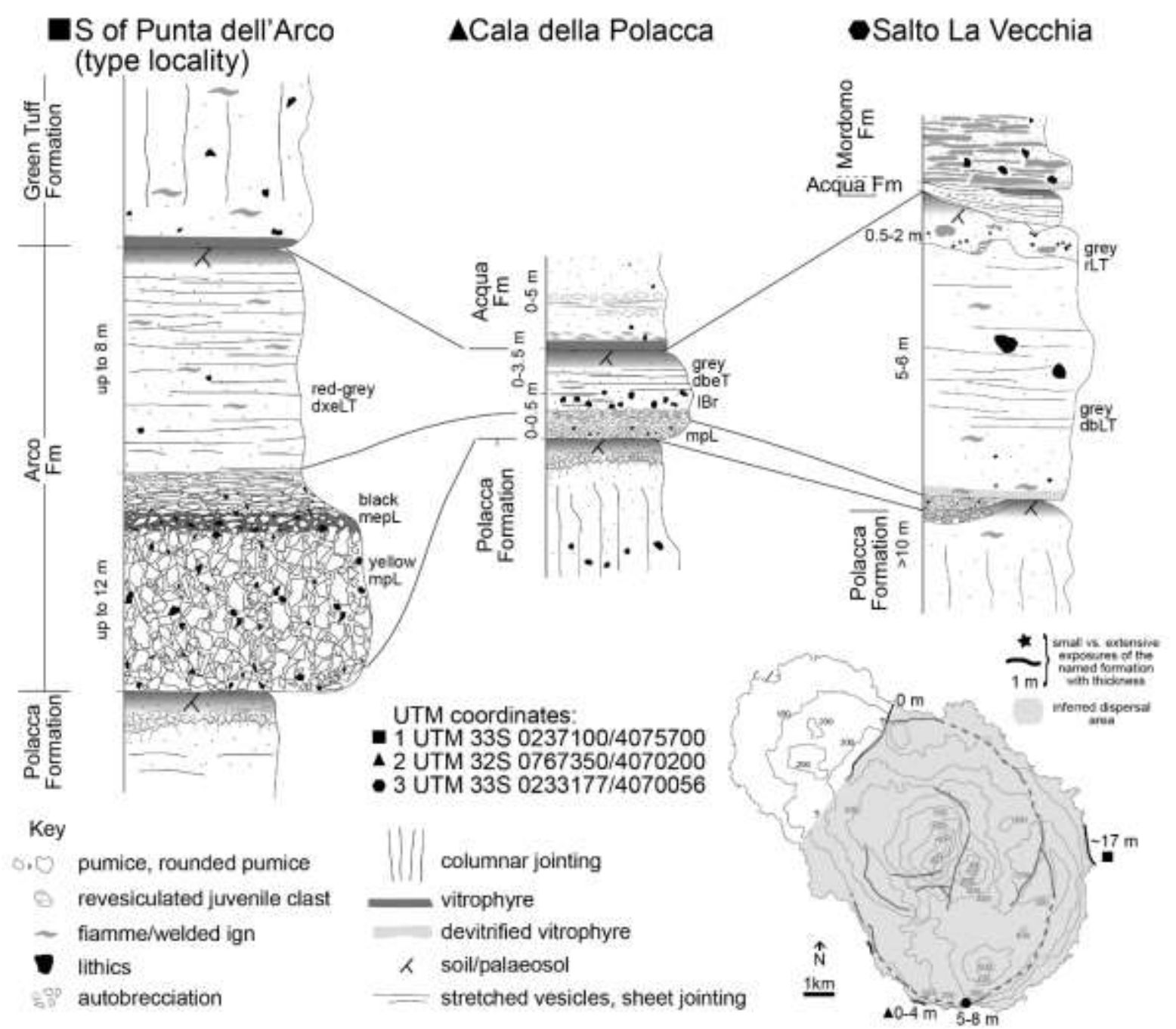

Figure 14. Logs of the Arco Formation at the type section (column 1) and other locations to show lateral variation of lithofacies. Sections contain units not shown here: only units in contact with the Arco Formation have been drawn. Map shows exposures of the Arco Formation and inferred dispersal area. It is unknown whether the current was able to overtop the Costa Zinedi topographic barrier. For most of the north-western part of the island the relevant stratigraphic levels are not exposed. 


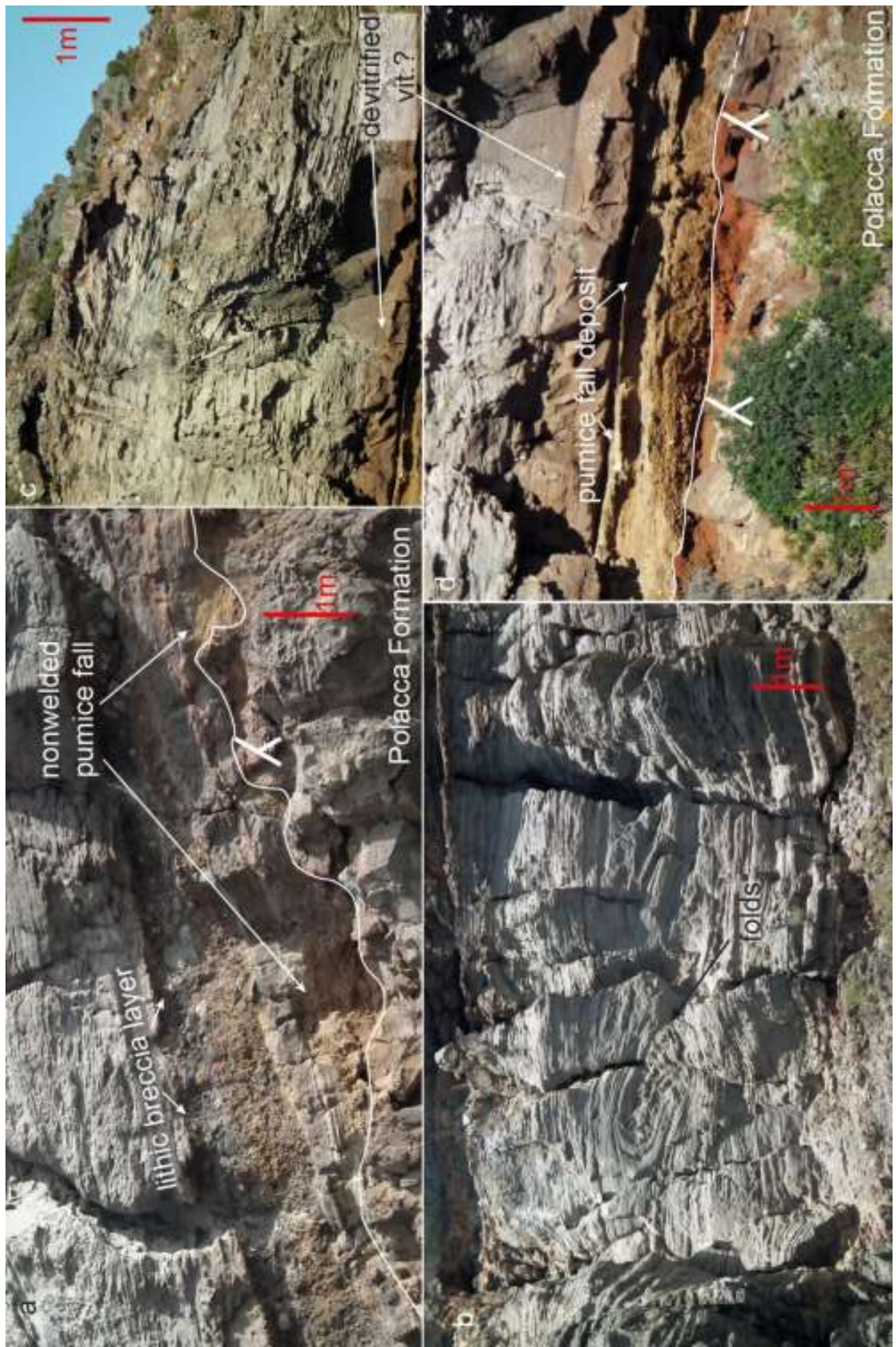

Figure 15. Lateral variation in the Arco Formation. A, b: Bedded appearance, rheomorphic folding and local breccia layers in the base of the ignimbrite (seen at Cala della Polacca). C, d: Bedded appearance and thin pumice-fall deposit (not accessible) at the base of the formation (seen at Salto La Vecchia).

\subsection{Polacca Formation}

\subsubsection{Definition}

The trachytic-rhyolitic Polacca Formation (new name) consists of a welded ignimbrite with local lithic breccias. It is capped by a weathering horizon at the top and overlies weathering horizons of older 
eruption-units (various older lavas along the south coast). In the GVS (Figure 2 ) it is thought to overlie the Pozzolana Formation but they are not seen in direct contact. It is overlain by the Arco Formation.

The type locality for this formation is a coastal section on the south coast of the Pantelleria at Cala Della Polacca (Figure 1) in a section only accessible by boat. Part of the ignimbrite is also accessible at Salto La Vecchia.

\subsubsection{Lithofacies}

At the type section the Polacca Formation is $\sim 8 \mathrm{~m}$ thick and consists of lithic-rich eutaxitic lapilli-tuff (at the base) and rheomorphic lapilli-tuff (at the top. Log: Figure 2). The middle portion is not accessible.

Description: The lithic-rich eutaxitic lapilli-tuff (leLT) lithofacies contains abundant lithic clasts (ML = $12 \mathrm{~cm}$ ) supported by a grey welded matrix. The clasts are locally imbricated, heterolithic and predominantly very fine-grained or glassy without crystals (Figure 16). The rheomorphic lapilli-tuff $(r L T)$ is reddish-grey with few small $(\leq 5 \mathrm{~cm})$ lithic clasts. No fiamme have been seen but there are abundant angular juvenile blocks, some of which are black and glassy, set in a weathered (red) matrix (Figure 16). Exposure is very limited ( $1 \mathrm{~m}$ thick).

The Polacca Formation is only exposed in southern and eastern areas of Pantelleria (Figure 17) which is largely a consequence of the topographic situation. Few of the exposed sections are accessible: the best exposed sections are at I Magazzinazzi and Cala della Polacca though these are only accessible from the sea.

The top of the Polacca Formation is exposed at I Magazzinazzi (Figure 17). Here, fiamme and rheomorphic folds can be seen more clearly than at the type locality. Lithic clasts average $11 \mathrm{~cm}$ in length. The formation can be seen to thicken and thin slightly (by 1-2 m) along the cliff, although not obviously in response to the underlying topography.

At some localities the Polacca Formation is diffusely bedded (e.g. Salto La Vecchia). The most striking lateral variation concerns the amount of lithic clasts. Lithic breccias or lithic-rich zones in the base of this formation have been seen on the east coast, on top of Cuddia di Scauri and at the base of the cliff below the village of Scauri. Due to limited access, data on these breccias are scarce but lithics are generally $10-20 \mathrm{~cm}$ (but may be as large as $\sim 1 \mathrm{~m}$ ) and dominated by hydrothermally altered clasts. Lithic clasts are matrix-supported at most localities but are locally clast-supported.

Interpretation: The Polacca Formation is one of the thicker and more uniform ignimbrites on Pantelleria. The black glassy blocks at the top at the type locality are interpreted as a strongly 
weathered autobrecciated top vitrophyre. The lithic-rich zones seen in several places all occur near topographic obstacles or in low-lying areas so their deposition was likely topography-controlled.

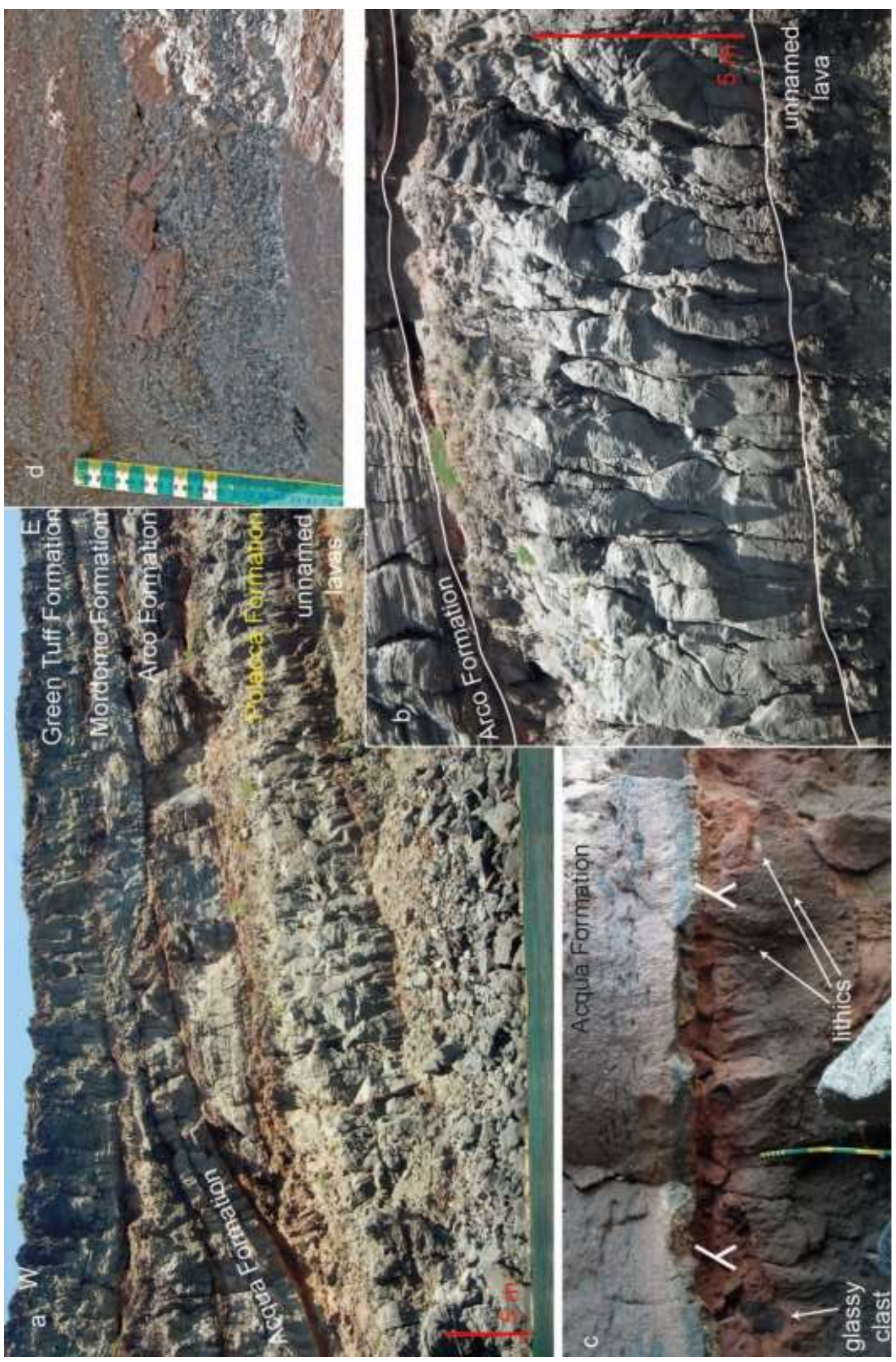

Figure 16. Defining the Polacca Formation at the type locality (Cala Della Polacca). A: The Polacca Formation in its stratigraphic context. B: Close-up showing columnar jointing and mostly massive appearance. Weathered top is locally recessed. C: Weathered top in cave at Punta Della Polacca with remnants of top vitrophyre. D: Imbricated lithic clasts in basal vitrophyre. Inferred current direction is to the left. 


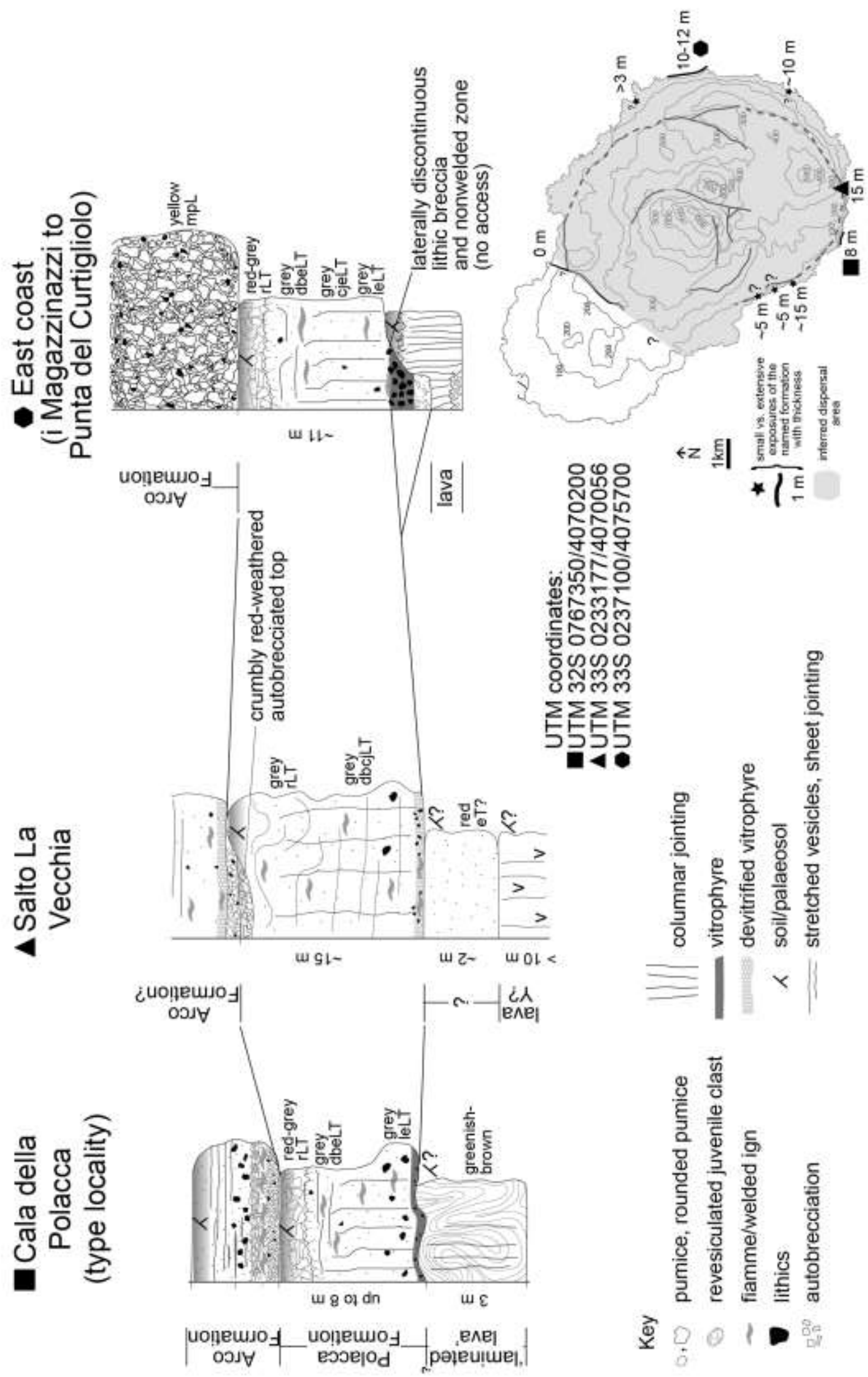

Figure 17. Fence diagram illustrating lateral variation within Polacca Formation in exposures across Pantelleria compared to the type section (column 1). Sections contain units not shown here: only units in contact with the Polacca Formation have been drawn. Map shows exposures (stars and lines) and inferred distribution (grey shading) of the Polacca Formation on Pantelleria. The relevant stratigraphic levels on the north coast are not exposed. 


\subsection{Pozzolana Formation}

\subsubsection{Definition}

The rhyolitic Pozzolana Formation (new name) consists of an ignimbrite with welded and nonwelded zones. It is considered an eruption-unit because it is capped by a weathering horizon at the top and overlies the weathering horizon of an older eruption-unit (Zinedi Formation). It is overlain by the Polacca Formation (not seen in direct contact in the field). The type area for this formation is on the north coast of the Pantelleria at Cala Della Pozzolana (Figure 1). The Pozzolana Formation has not been dated radioisotopically. It is bracketed in the field by the Zinedi Formation (189 ka) and the Cinque Denti Formation (128 ka) so its minimum age is $128 \mathrm{ka}$. In the General Vertical Stratigraphy (Figure 2 ) it is thought to be overlain by the Polacca Formation (187 ka) so we may speculate it age is closer to 187-188 ka. However, it is not seen in direct contact with the Polacca Formation.

\subsubsection{Lithofacies}

At the type section the Pozzolana Formation comprises two lithofacies: thin-bedded pumiceous block and lapilli-tuff (at the bottom) and eutaxitic lapilli-tuff (at the top. Log: Figure 2).

\section{Thin-bedded pumiceous block and lapilli-tuff (bpBLT)}

Description: The thin-bedded pumiceous block and lapilli-tuff is white, very poorly sorted and contains subrounded to rounded pumice clasts (few subangular pumice clasts have been seen) which are variably clast or matrix-supported. Beds alternate between coarse (lapilli) and fine (ash) and are commonly a few metres long, then taper (Figure 18a, b). The deposit is relatively lithic-poor with only $\sim 5$ vol\% lithic clasts. Lithic clasts average $5 \mathrm{~cm}$ in length but the longest are $10 \mathrm{~cm}$. Pumice clasts average $9 \mathrm{~cm}$ but the longest are $16 \mathrm{~cm}$. The average length: thickness ratio of 20 measured pumice clasts is 1.3 , i.e. the pumice clasts are nearly all equant. Vesicularity in pumice clasts is on the order of 50 vol\% or more and phenocryst content in pumice clasts is $<10$ vol\%, although within the ash fraction of the deposit crystal-rich layers have been observed.

Interpretation: The thin-bedded pumiceous block and lapilli-tuff is interpreted as a pyroclastic density current deposit based on its very poor sorting and laterally impersistent beds. The rounded pumice clasts and crystal-rich layers may indicate that pumice clasts have been abraded and crystals have been released from them. The clast-supported beds with subangular pumice clasts are atypical for ignimbrites and may indicate a fallout component. Similar 'mixed' or 'hybrid' deposits have been observed at the base of the Green Tuff Formation (Williams, 2010) and elsewhere (e.g. Ecuador, mainland Italy) and are inferred to record simultaneous deposition from fallout and lateral currents (Valentine \& Giannetti, 1995; Di Muro et al., 2004; Di Muro et al., 2008). 


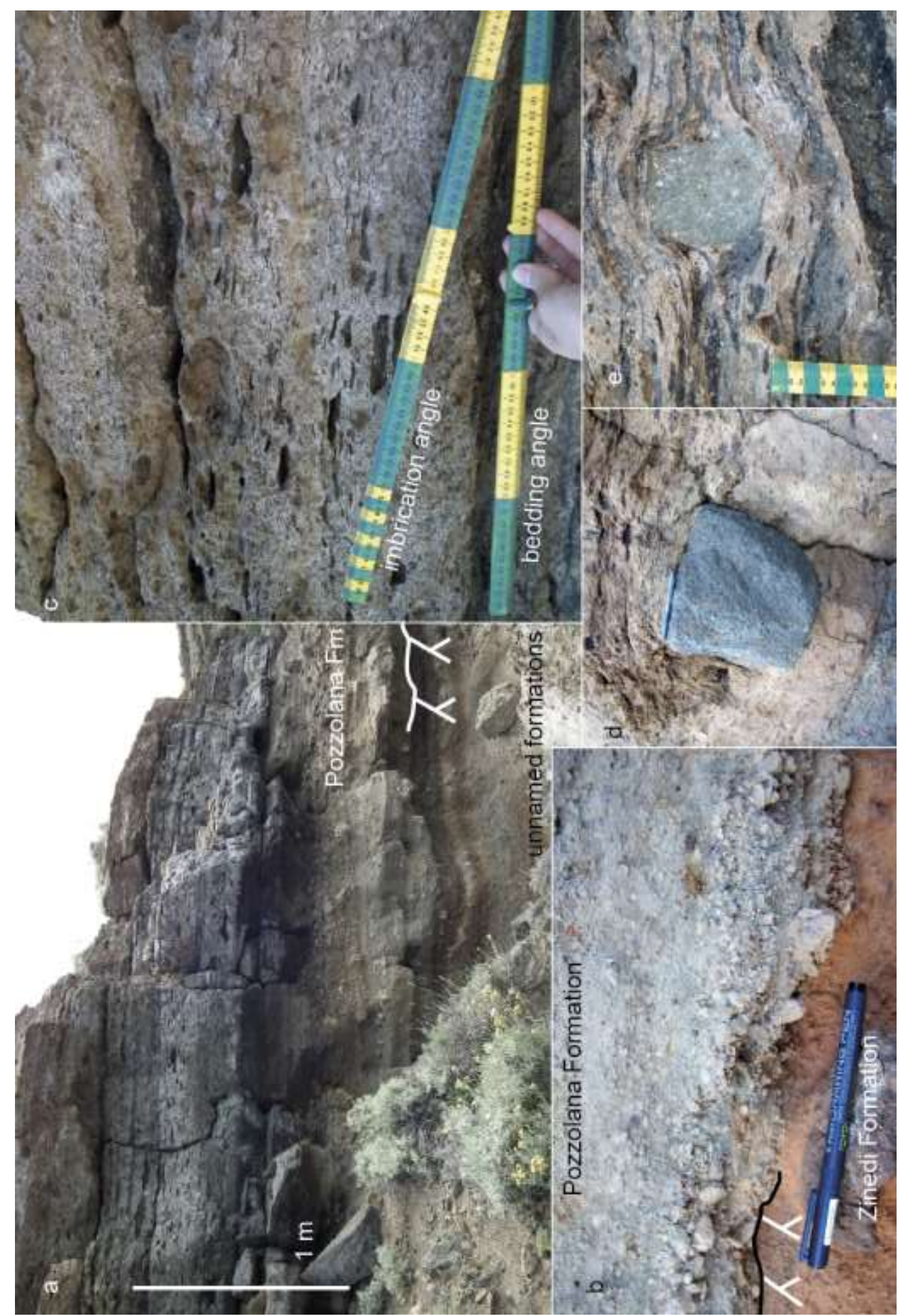

Figure 18. Field photos of the Pozzolana Formation in the type area at Cala Della Pozzolana. A: Overview of the formation showing both welded and non-welded facies. Note black transition zone. Top not shown. B: Closeup of the base of the Pozzolana Formation showing round pumice clasts. C: Imbricated fiamme in upper part of the Pozzolana Formation (not compatible with air-fall origin). D: Example of large lithic block in upper part of the Pozzolana Formation. E: Example of hot ductile fiamme moulded around a cold lithic clast. 


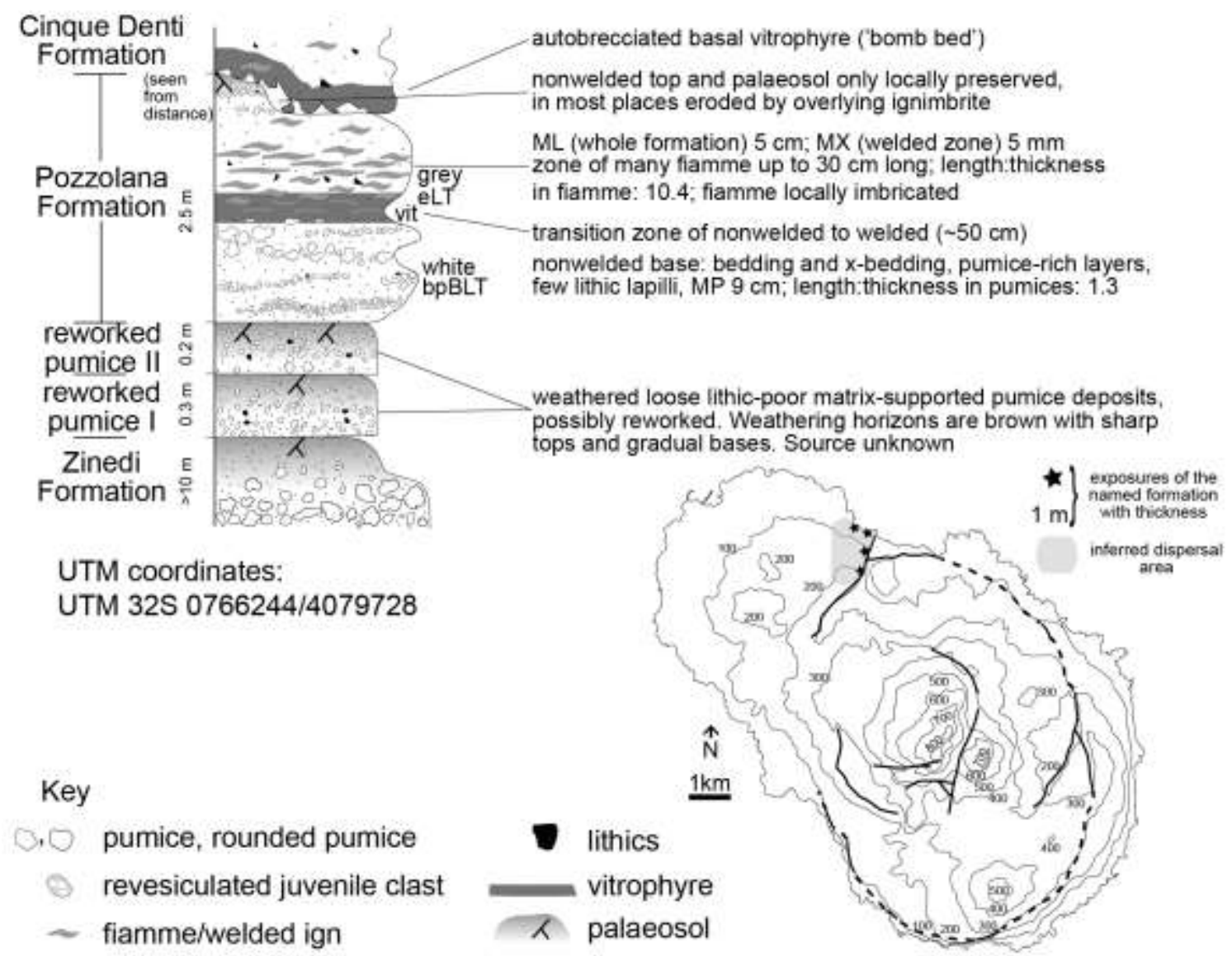

Figure 19. Graphic log of the Pozzolana Formation in stratigraphic context at the type section in and around Cala della Pozzolana. Lateral variation is negligible. Map shows exposures (stars) and inferred minimum distribution (grey shading) of the Pozzolana Formation on Pantelleria. The formation has not been seen elsewhere.

\section{Eutaxitic lapilli-tuff (eLT)}

Description: The transition upward from the underlying lithofacies is gradual and is marked by a $\sim 30 \mathrm{~cm}$ thick black layer (Figure 18a). The eutaxitic lapilli-tuff contains abundant black fiamme (max. $70 \mathrm{~cm}$ long, average $16 \mathrm{~cm}$ ) set in a beige ash matrix. They can be seen to be moulded around lithic clasts (Figure 18e). The length: thickness ratio in the fiamme is on average 10 (compare equant pumice clasts above), demonstrating the flattening effect that welding has on pumice clasts. Fiamme are oblate, not prolate, and are locally imbricated (dipping toward the centre of the island, Figure 18c). Lithic clasts are on average $5 \mathrm{~cm}$ in length but few reach $>20 \mathrm{~cm}$ (Figure 18d). The amount of lithic clasts and fiamme varies vertically and laterally.

Interpretation: The eutaxitic lapilli-tuff is interpreted as a welded ignimbrite based on its very poor sorting, imbricated fiamme and lateral variability. The black layer at the base may be a vitrophyre where the welded ignimbrite chilled against the non-welded deposit below. 
The Pozzolana Formation shows limited lateral variation as it is only exposed in the area around Punta/Cala Della Pozzolana (Figure 19). Its thickness is relatively constant at 2-3 m. It has not been found along the south coast.

Around Cala Della Pozzolana (type locality) the top of the Pozzolana Formation coincides with the top of the welded part and is directly overlain by the Cinque Denti Ignimbrite (no palaeosol) or is not overlain by any formation. However, when traced north-westward to II Porticello (see Figure 1 for locations) the formation can be seen to comprise a $\sim 2 \mathrm{~m}$ thick non-welded top similar to its base (Jordan, 2014). It is interesting to note that at the type locality, where the Pozzolana Formation is overlain by an ignimbrite, the loose pumice layers are not preserved (Figure 19). At II Porticello however, where these are capped by a lava, the ignimbrite did not come into direct contact with the pumice layers and so could not erode them. This is indicative of the ability of pyroclastic density currents to erode soft substrates, which can make stratigraphic correlations difficult.

\subsection{Zinedi Formation}

\subsubsection{Definition}

The trachytic-rhyolitic Zinedi Formation (new name) consists of a lava overlain by a mostly massive non-welded ignimbrite. It is bounded by weathering horizons at the top and base (in the top of a pumice fall deposit seen at Punta Pozzolana) and is interpreted as an eruption-unit. It is overlain by the Pozzolana Formation.

The type locality for the Zinedi Formation is at Punta Pozzolana on the north coast of Pantelleria (Figure 1). It is named after the nearby Zinedi scarp where it is also well exposed.

\subsubsection{Lithofacies}

Description: In the type area the Zinedi Formation is a 15 $\mathrm{m}$ thick grey non-welded clast-supported pumice-rich ash-lapilli deposit interpreted as an ignimbrite (log: Figure 2, field photos: ). Pumice clasts are subrounded to subangular and some have denser glassy interiors. Pumice clasts average $29 \mathrm{~cm}$ and lithic clasts average $12 \mathrm{~cm}$ although rare lithic blocks measuring $84 \mathrm{~cm}$ occur, whereas the largest pumice found was $54 \mathrm{~cm}$ long. The proportion of hydrothermally altered lithic clasts (30-50 \% of all lithic clasts) is much higher than in other eruption-units. The deposit appears massive from afar though variations in the amount of ash matrix have been seen. A $5 \mathrm{~m}$ long lens of coarse pumice clasts near the top of the Zinedi Formation contains pumice clasts of $\sim 5-10 \mathrm{~cm}$ set in pumice clasts of dominantly $1-3 \mathrm{~cm}$ (). In the base of the formation is a discontinuous $10 \mathrm{~cm}$ thick ash layer, locally disturbed by $20-30 \mathrm{~cm}$ large clasts that protrude from the ash into the underlying soil. No imbrication of clasts was seen anywhere in the formation. Granulometry data (Jordan, 2014) plot in the pyroclastic density currents field and outside the Plinian fall field of Walker (1983). 
The Zinedi Formation can be traced along the Zinedi scarp for $~ 2.5 \mathrm{~km}$ (Figure 21) with little thickness variation except for one location (Figure 22) where it varies in thickness between $1 \mathrm{~m}$ and $3 \mathrm{~m}$ over $<50 \mathrm{~m}$ distance. The top of the formation is flat (i.e. valley-filling) and the thickness variation is in response to the irregular topography of the underlying lava (Figure 22). There is no soil in the top of the lava so it is considered part of the Zinedi Formation. The lava is a black, feldsparphyric, heavily jointed and autobrecciated pantellerite. Blocks of it can be found in the overlying ignimbrite (Figure 22).
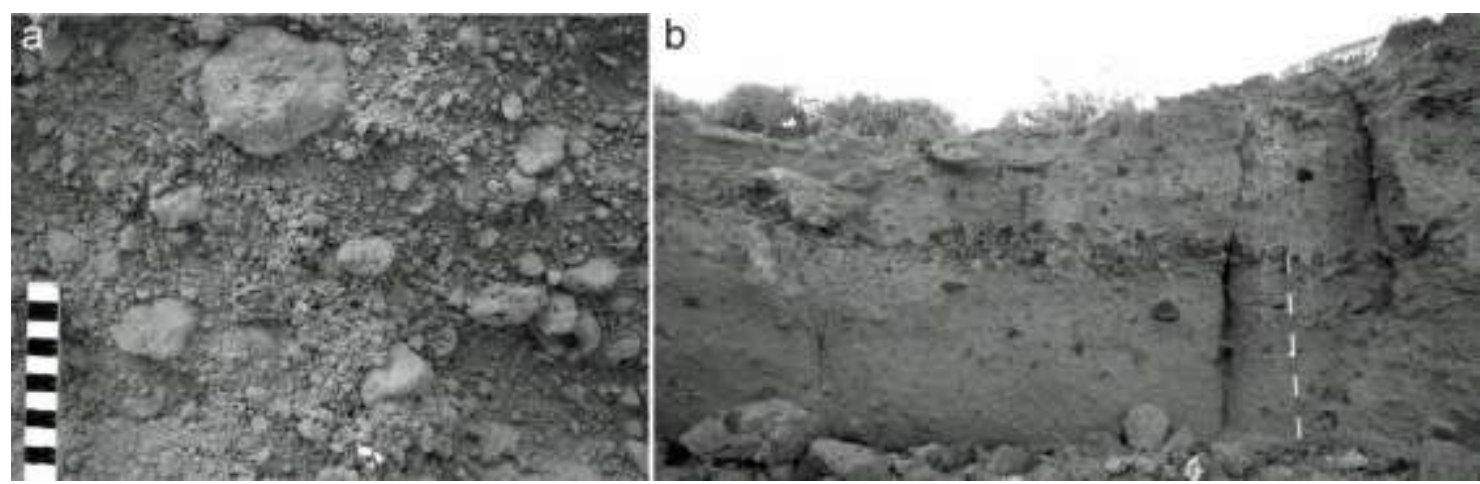

Figure 20. Typical appearance of the Zinedi Formation, containing rounded pumice clasts, variable grain sizes (a) and lenses of larger pumice (b).

Interpretation: The Zinedi Formation lapilli-ash deposit is interesting as it has features of both fall (clast-supported, block sags) and lateral flow (subrounded pumice clasts, subtle bedding) origin. The block sags at the base of the formation are more likely to be of ballistic origin and indicate proximity to the vent. The deposit is interpreted to be an ignimbrite on the basis of its subrounded pumice clasts (indicative of abrasion), local subtle discontinuous bedding and lenses and thinning over topographic highs. The absence of welding contrasts with other ignimbrites on Pantelleria and may reflect a lower magmatic temperature in this eruption-unit compared to others (e.g. Freundt, 1999) or a lower eruption mass flux.

The large amount of hydrothermally altered clasts among the lithic clasts in this formation may indicate the presence of an active hydrothermal system in the volcano at the time of the Zinedi eruption. While it cannot be ruled out, it is not known whether or not this triggered the eruption (Pittari et al., 2008).

The presence of blocks of lava in the overlying ignimbrite may indicate erosion by the density current as it travelled across the lava. As it is more usual in Pantescan eruptions for the lava to erupt after the explosive event (e.g. Rotolo et al., 2007), we can speculate that there may have been a palaeosol on top of the lava that has been eroded by the current that deposited the ignimbrite. However, since no soil or weathering horizon has been seen the lava is considered part of the Zinedi Formation. 


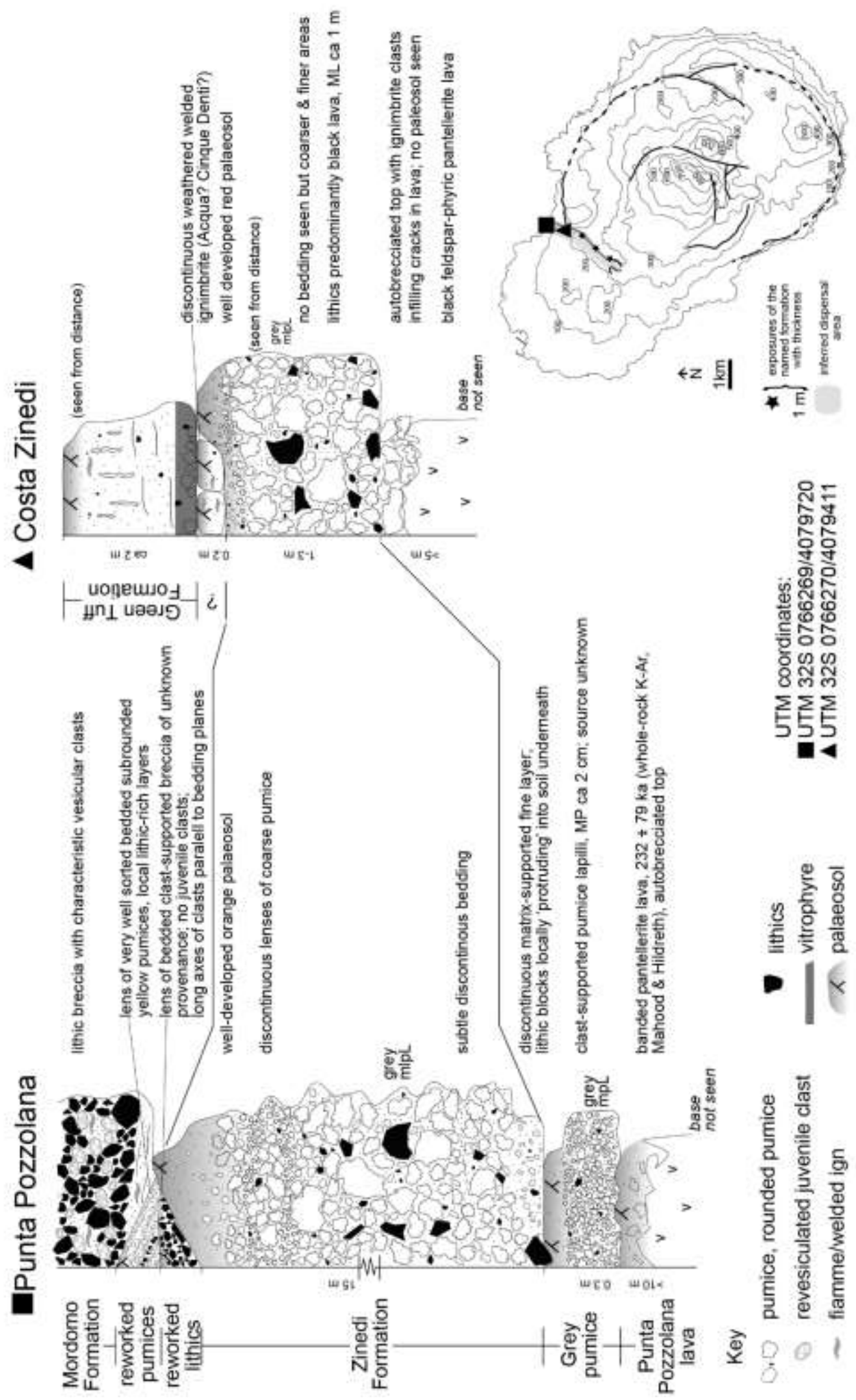

Figure 21. The Zinedi Formation in stratigraphic context at the type locality (column 1) and further along the Zinedi scarp illustrating minor lateral variations. Map shows exposures (stars) and inferred minimum distribution (grey shading) of the Zinedi Formation on Pantelleria. The formation has not been seen elsewhere. 

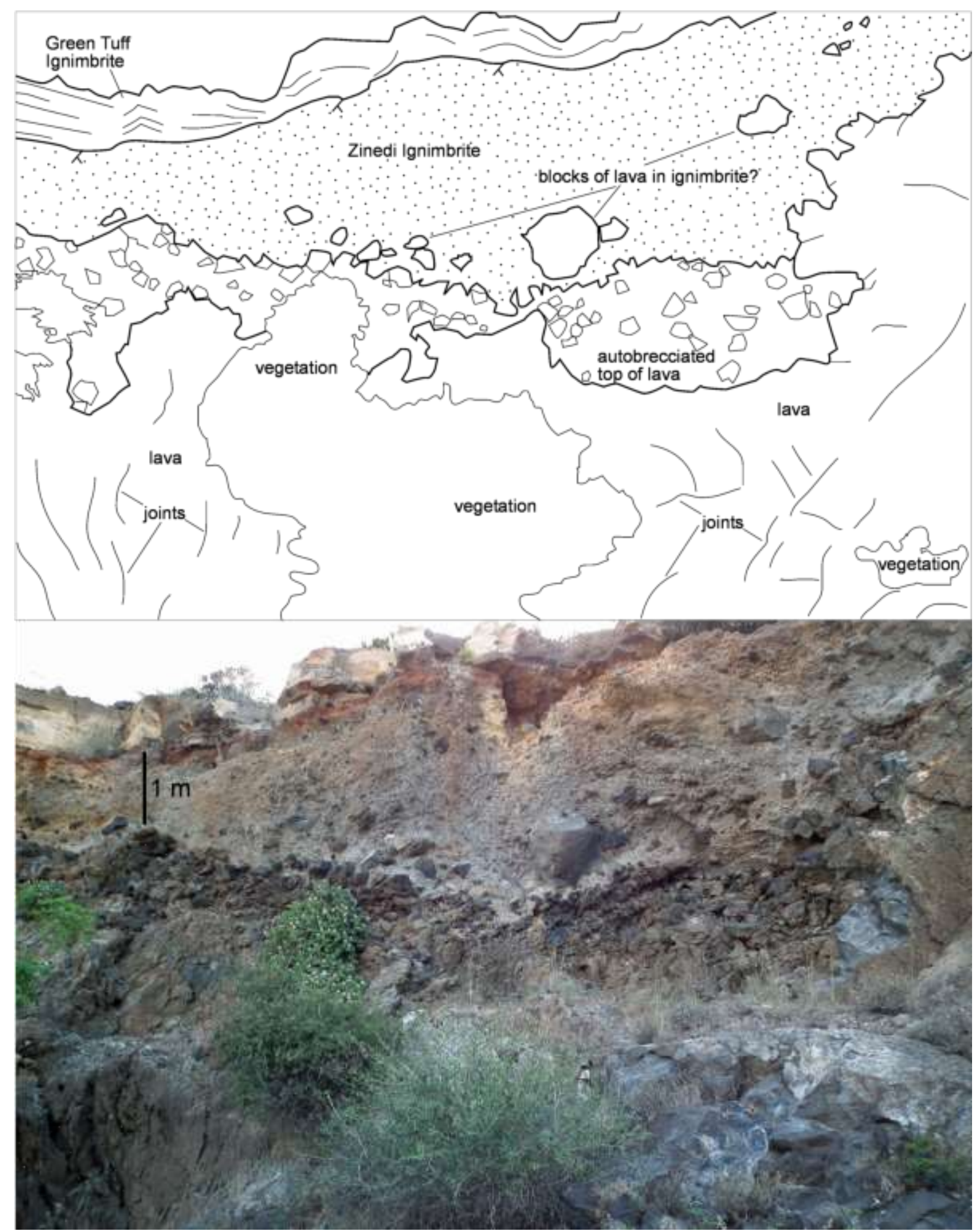

Figure 22. Photo and sketch illustrating lateral thickness changes in the Zinedi Formation along the Costa Zinedi scarp (same location as column 2 in Figure 21). Also note the underlying lava - thought to be part of the Zinedi Formation - which is not seen at the type location.

\section{Inter-ignimbrite activity}

The products of large explosive eruptions can be traced across large parts of the island and thus serve as tie-lines to provide relative ages for the small, monogenetic eruptions. Their definition 
includes any eruptive product of limited extent and volume that is separated from a large eruption by a weathering horizon or palaeosol. However, we have not named and defined every single centre along the south coast because in many places there are stacks of several (four or five) lavas underneath the ignimbrites, each with a palaeosol, and it is likely that the same area has been the site of recurring eruptions for a length of time.

Most of the coast between Scauri and Punta dell'Arco consists of steep cliffs as high as $~ 300 \mathrm{~m}$ with many pumice deposits and lavas. These do not trace laterally further than a few hundred metres. Cliff sections are locally draped by welded ignimbrites or younger lavas and are thus not continuous. It is therefore difficult to present a good stratigraphic account and put these eruption-units into a definite order. This is further hampered by the absence of $>187 \mathrm{ka}$ ignimbrites as tracing tools. The stratigraphic control is much better $<187 \mathrm{ka}$ when the ignimbrites can be used to constrain relative ages (usually minimum ages because the base is rarely exposed).

Nearly 20 pre-Green Tuff centres (monogenetic volcanoes) have been mapped across Pantelleria (Figure 23, Figure 24). There is a compositional separation between felsic and mafic eruptions: mafic eruptions occurred only in the northwest of the island whereas felsic eruptions occurred only in the larger southeast part of the island, a pattern also seen in the post-Green Tuff period (Mahood \& Hildreth, 1986). Most of these peripheral volcanoes have erupted lava and pumice falls, i.e. have produced effusive and explosive eruptions, but some have only produced one or the other. A few centres (Gadir, Cala delle Giache, Cala delle Capre) have produced small-scale density currents depositing non-welded poorly sorted pumice.

In order to constrain a maximum subaerial eruption age of the volcano, we have selected one of the lowermost pantellerite lavas from the south coast (W of Balata dei Turchi) for radioisotopic dating: it has a feldspar Ar-Ar age of $257 \pm 2$ ka (section A.3 in Appendix).

Until accurate radioisotopic dates of more of the inter-ignimbrite volcanoes become available, it is not possible to assess the frequency of these eruptions and whether they occur in time clusters or regularly. However, it is clear that this 'background' activity has been going on for the entire subaerial history of the volcano and we may speculate that it has also occurred during the submarine history. For the more recent (<20 ka) post-GT eruptions, millennial-scale Ar/Ar dating has revealed a decrease in eruptive pace since 14 ka which may be linked to a rising sea-level occurring since at least $21 \mathrm{ka}$ (Scaillet et al., 2011). It remains to be seen whether any future eruptions will occur on the island but we are reluctant to rule this out. 


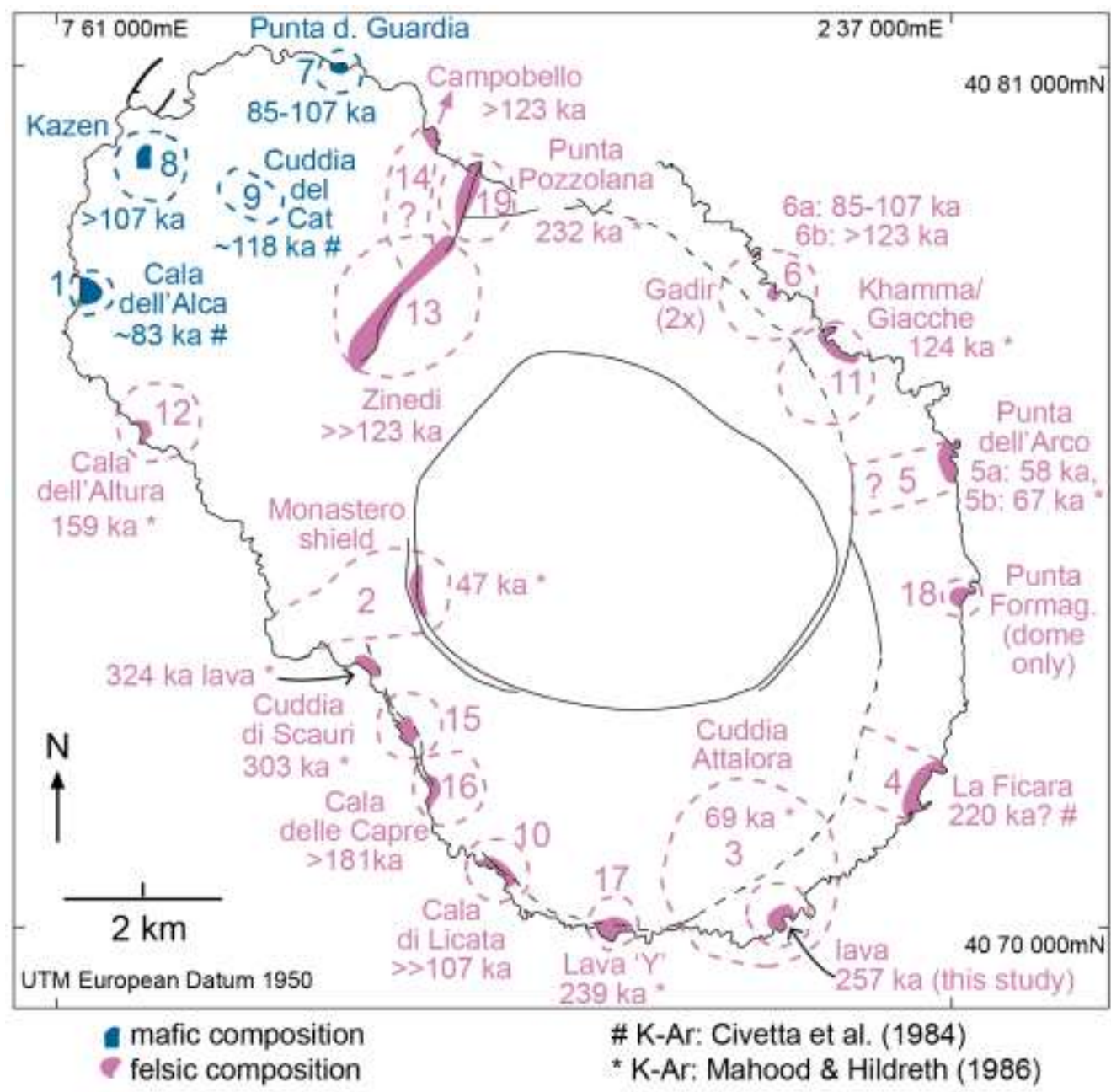

Figure 23. Map of pre-Green Tuff monogenetic volcanoes. Numbering is for orientation only (corresponding to Figure 24) and is not in chronological order. Filled shapes are outcrops, dashed lines indicate inferred approximate footprint from a combination of literature and fieldwork data (in most cases thought to lie on caldera faults). Post-Green Tuff centres are omitted for clarity. Ages are quoted from the literature where the deposit has been dated directly. Relative ages for some centres can be constrained by the enclosing stratigraphy (see below). Division into centres can be arbitrary as much of the coast between C. Di Licata and P. Dell'Arco consists of stacks of lavas and pumice falls, most of which separated by weathering horizons. 


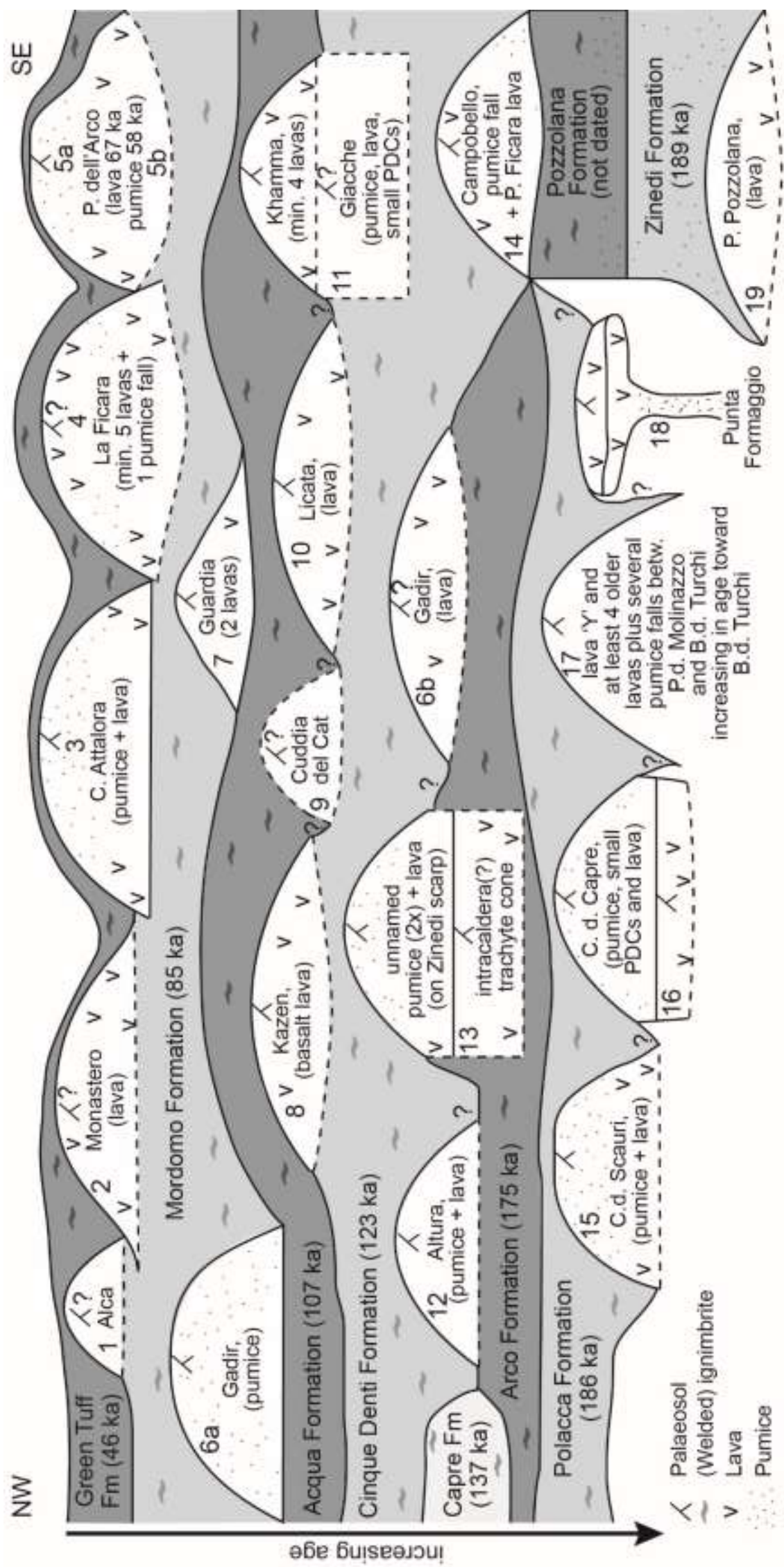

Figure 24. Schematic chronological representation of pre-Green-Tuff monogenetic volcanoes in context with the ignimbrite formations. Dashed line indicates the basal contact is not seen. Where information was available centres are shown as either broad shields or steep cones. Some location names have been shortened. Numbers refer to map in previous figure. 


\section{Discussion}

\subsection{Interpretation of paleomagnetic data}

The mean paleomagnetic directions obtained from the ignimbrites on Pantelleria have been shown to be sufficiently different between volcanic units as to be useful to discriminate between them, while being sufficiently similar within a unit to be more or less unique (Speranza et al., 2012). For example, previously obtained data had been used to confirm the re-assignment of some exposures (cos15) of the Acqua Formation ('Unit Q' of Mahood \& Hildreth, 1986) to the Cinque Denti Formation ('Unit P'; Speranza et al., 2012). Here, we add data obtained from the older units (Arco, Polacca, Pozzolana and Zinedi Formations) to previously published results (Figure 25).

The Arco and Polacca Formations yield $6^{\circ}$ to $24^{\circ}$ declinations and inclinations as low as $35^{\circ}-43^{\circ}$ (Figure 25). The two sets of results for the Arco and Polacca Formations at the Scauri and Salto La Vecchia locations are similar enough (less than $10^{\circ}$ of angular distance) to be able to correlate them. However, a systematic difference of paleomagnetic directions also indicates that the Scauri outcrop was tilted by some $5^{\circ} \mathrm{NW}$-ward with respect to Salto La Vecchia, where the lack of tilting is guaranteed by the consistency of the paleomagnetic directions obtained in the Mordomo and Acqua Formations (Speranza et al., 2012).

Due to its limited exposure in the north of the island we only have one result for the Pozzolana Formation ( $345^{\circ}$ declination), which overlaps completely with the directions in the Cinque Denti Formation. This could either be incidental (paleomagnetic directions can be re-occupied over time) or may show that the time between the two eruptions was very short ( $<200$ years). Lastly, it may be due to an overprinting of the remanent magnetization in the Pozzolana Formation due to heating by the overlying Cinque Denti ignimbrite. This could be clarified using more exposures of the Pozzolana Formation or comparing radioisotopic dates for both formations. 


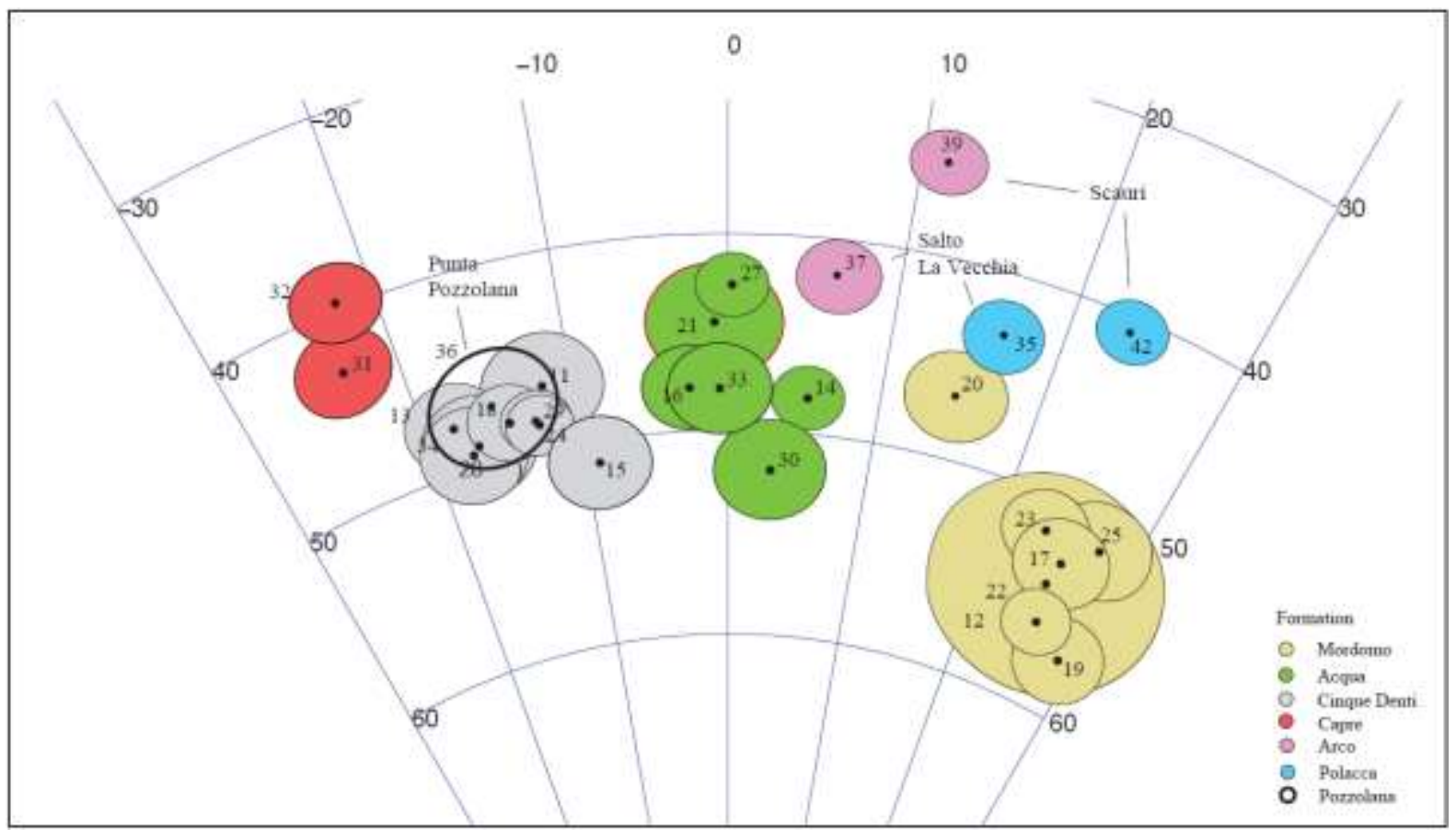

Figure 25. Equal-area projection (lower hemisphere) of mean paleomagnetic directions from ignimbrites of Pantelleria (the "cos" suffix of each site is omitted), and updated formation attribution. Ellipses about the paleomagnetic directions are the projections of the relative $\alpha_{95}$ confidence cones. Sites Cos 11 -Cos34 are from Speranza et al. (2012), sites Cos35-Cos42 are from this study. The directions of sites $\operatorname{Cos} 13, \operatorname{Cos} 18, \operatorname{and} \operatorname{Cos} 32$ were changed to account for local outcrop tilting (e.g. Speranza et al., 2012).

\subsection{A new stratigraphy}

The ignimbrite formations defined in this study have simplified the previous stratigraphic schemes (Table 1) and type localities have been defined for the first time. Most of the ignimbrites are welded but many have local areas or discrete beds that are non-welded (Green Tuff, Mordomo, Arco and Pozzolana Formations, possibly Polacca Formation). The ignimbrite-forming eruptions are typically characterised by eutaxitic lapilli-tuff with either local or extensive lithic breccias. Almost all are locally rheomorphic. Some ignimbrites are associated with thin pumice falls of limited extent, likely representing subplinian or smaller eruption columns. The ignimbrite formations and their key characteristics are summarised in Table 3.

Before $~ 189$ ka there are no known ignimbrite eruptions. The oldest part of the island was thought to be the cliff between Salto La Vecchia and Balata Dei Turchi on the south coast, and it was assumed that eruption-units become younger toward either side of this location due to their dip. This correlates with the highest cliff sections being located in the southeast of the island and the gentlest slopes being in the northwest of the island (a long-term north-westward migration of the volcanism has been proposed by Mahood \& Hildreth, 1986). However, an Ar-Ar date from this section gave a surprisingly young age of $257 \pm 2$ ka (Appendix A.3). The island's subaerial volcanic history may therefore be shorter than anticipated. 
Small-scale effusive and explosive eruptions have continued throughout the island's history and may be thought of as a 'background activity' to the ignimbrite eruptions. We therefore do not support the idea of dividing the island's volcanic history into 'cycles' (cf. Civetta et al., 1984). We currently do not have enough information to say whether they occur in time clusters or equally spaced. However, it is clear that this 'background' activity has been going on for the entire subaerial history of the volcano.

We also refrain from using terms such as pre or post-caldera as we have shown that caldera collapse may occur several times in a volcano's lifetime (see below) and that both the large and small eruptions are a persistent feature of the volcanic history. 
Table 3. Summary of physical appearance and typical features of ignimbrite formations.

\begin{tabular}{|c|c|c|c|c|c|c|}
\hline Formation & $\begin{array}{l}\text { Pumice } \\
\text { fall? }\end{array}$ & $\begin{array}{l}\text { Lithic } \\
\text { breccia? }\end{array}$ & $\begin{array}{l}\text { Erupted } \\
\text { over whole } \\
\text { island? }\end{array}$ & Welded? & $\begin{array}{l}\text { Characteristic } \\
\text { features }\end{array}$ & Eruption summary \\
\hline $\begin{array}{l}\text { Green } \\
\text { Tuff }\end{array}$ & $\begin{array}{l}\text { Yes (below } \\
\text { ignimbrite) }\end{array}$ & Yes & Yes & Yes & Green colour & $\begin{array}{l}\text { Produced an initial subplinian column depositing a local non-welded } \\
\text { pumice fall followed by a diachronous quasi-steady pyroclastic density } \\
\text { current depositing a mostly rheomorphic ignimbrite island-wide } \\
\text { (Williams, } 2010 \& 2014 \text { ). Potential caldera-forming unit. }\end{array}$ \\
\hline Mordomo & No & Yes & Probably & Yes & $\begin{array}{l}\text { Revesiculated } \\
\text { clasts }\end{array}$ & $\begin{array}{l}\text { Produced a welded, locally rheomorphic, ignimbrite covering most of } \\
\text { Pantelleria. Lithic breccias are present at the base (cognate) and top } \\
\text { (accidental/accessory) of the ignimbrite and revesiculation of juvenile } \\
\text { pumice clasts is ubiquitous. Potential caldera-forming unit. }\end{array}$ \\
\hline Acqua & No & Yes & No? & Yes & $\begin{array}{l}\text { Lithic breccia, } \\
\text { large feldspars }\end{array}$ & $\begin{array}{l}\text { Produced a welded, locally rheomorphic, ignimbrite covering most of } \\
\text { Pantelleria. Its thick lithic breccia (only deposited northwards) is a likely } \\
\text { indicator of caldera formation. Potential caldera-forming unit. }\end{array}$ \\
\hline $\begin{array}{l}\text { Cinque } \\
\text { Denti }\end{array}$ & $\begin{array}{l}\text { Yes (above } \\
\text { ignimbrite) }\end{array}$ & No & No & Yes & $\begin{array}{l}\text { Strongly } \\
\text { rheomorphic. } \\
\text { Largest } \\
\text { feldspars }\end{array}$ & $\begin{array}{l}\text { Produced a widespread thick rheomorphic ignimbrite with } \\
\text { characteristically large and abundant feldspars. After a break the } \\
\text { eruption continued with a subplinian pumice fall. }\end{array}$ \\
\hline Capre & $\begin{array}{l}\text { Yes (below } \\
\text { ignimbrite) }\end{array}$ & Yes & No & Yes & Very lithic-rich & $\begin{array}{l}\text { Produced a large, possibly climactic eruption depositing a thick lithic-rich } \\
\text { ignimbrite that may have ponded inside the caldera. It was preceded by a } \\
\text { thin precursory pumice fallout. Potential caldera-forming unit. }\end{array}$ \\
\hline Arco & $\begin{array}{l}\text { Yes (below } \\
\text { ignimbrite) }\end{array}$ & No? & Yes? & Yes & $\begin{array}{l}\text { Bedded } \\
\text { appearance }\end{array}$ & $\begin{array}{l}\text { Produced a subplinian pumice fall from a vent in the east of the island } \\
\text { and climaxed with the eruption over much of the island of a welded } \\
\text { ignimbrite containing local breccia lenses. }\end{array}$ \\
\hline Polacca & No & Yes & Yes? & Yes & $\begin{array}{l}\text { Very thick. } \\
\text { Lithic-rich } \\
\text { base }\end{array}$ & $\begin{array}{l}\text { Produced the thickest welded ignimbrite of all Pantescan ignimbrites. It } \\
\text { has possibly been erupted over most of the island and contains local } \\
\text { lithic breccias. Potential caldera-forming unit. }\end{array}$ \\
\hline Pozzolana & Probably & No & No & Partly & Part-welding & $\begin{array}{l}\text { Produced a part-welded ignimbrite with restricted distribution, only } \\
\text { occurring in the north of Pantelleria. Contains local beds of fallout origin. }\end{array}$ \\
\hline Zinedi & No? & No & No & No & $\begin{array}{l}\text { Hydrothermal } \\
\text { clasts }\end{array}$ & $\begin{array}{l}\text { Produced a non-welded pumice-rich ignimbrite with restricted } \\
\text { distribution in northern Pantelleria. }\end{array}$ \\
\hline
\end{tabular}




\subsection{Caldera collapse}

Most of the ignimbrite formations on Pantelleria (the Green Tuff, Mordomo, Acqua, Capre and Polacca Formations) have variably widespread lithic breccias. Of these, the Acqua breccia is the thickest at $\sim 4 \mathrm{~m}$. The Arco Formation also contains a significant breccia horizon (seen at Cala Della Polacca, Figure 15a). Smaller breccias or breccia lenses occur in the other formations.

Lithic breccias (i.e. proximal, coarse, clast-supported deposits of lithic clasts grading vertically and laterally into ignimbrites (Druitt \& Sparks, 1982)), if composed of plutonic clasts or clasts derived from inside the vent (e.g. Palladino et al., 2014), represent an energetic phase of ignimbrite eruptions coupled with vent erosion or widening and are commonly thought to indicate caldera collapse phases of such eruptions (Druitt, 1985; Walker, 1985; Druitt \& Bacon, 1986). Therefore, five formations may reasonably be inferred to have undergone partial or complete caldera collapse as inferred from the presence of lithic breccias (Table 3). Lithic breccias that are comprised of surfacederived clasts are the result of substrate erosion by the pyroclastic density current and are not interpreted to represent caldera-collapse.

It was widely believed that there have been two caldera collapse events (e.g. Mahood \& Hildreth, 1986) even though the lithic breccias had until now not been quantified. While there are clearly two topographic calderas, faults can be re-used during successive eruptions (Cole et al., 2005), such as the Costa Zinedi scarp, which is thought to be the northern scarp for both calderas (Figure 1). Lithic breccias containing plutonic lithic clasts are identified in the Mordomo Formation (breccia A) and in the Acqua Formation, representing caldera collapse events during these eruptions. Furthermore, breccia lenses have been found in the Cinque Denti, Arco and Polacca Formations but they are not widespread nor at the same horizon everywhere, and may therefore represent only partial collapse. The thin breccia lenses in the Green Tuff Formation are largely locally-derived through erosion of the substrate and those containing plutonic clasts are thin and not traceable over large distances (Williams, 2010). Thus it is unlikely that significant caldera collapse occurred during this eruption as previously assumed (e.g., Civetta et al., 1988; Orsi et al., 1991), but more likely only minor reactivation of caldera scarps. Therefore, there may have been at least two, but likely five (or more), caldera collapse events on Pantelleria.

\subsection{Ignimbrite eruption volumes}

Eruption volumes are difficult to obtain due to the limited outcrop of older units and small size of the island. Published on-land volume estimates for the Green Tuff Ignimbrite range from 0.41 to $0.5 \mathrm{~km}^{3}$ dense rock equivalent (DRE, Wolff \& Wright, 1981; Civetta et al., 1988; Williams et al., 2014). Volume estimates for other ignimbrites range from 0.19 to $0.46 \mathrm{~km}^{3}$ DRE (Rotolo et al., 2013). On 
Pantelleria, caldera infill volumes are unknown because the caldera is filled with younger material and alluvium. Erosion is thought to be limited due to the ignimbrites being strongly welded. Erosion does occur in the sea cliffs though its rate is unknown.

One approach to obtain volumes may be to estimate an average thickness for a given eruption product from as many locations as possible and to calculate an area by interpolating between these areas (Rotolo et al., 2013) although this does not take into account that exposure is generally worse for older eruptions or that ignimbrites may erode any early (non-welded) eruptive products.

Previous studies have calculated volumes based only on the confirmed exposures as currently seen in sea cliffs. The aerial distribution of ignimbrites has now been determined much more accurately (see maps in ignimbrite sections) and we use these to obtain internally-consistent onshore volumes estimates for all nine ignimbrite formations. Also, we have assumed that originally each ignimbrite was deposited over most or all of the island, similar to the Green Tuff ignimbrite, unless there is reason to think otherwise. The new volumes and thickness assumptions based on this study are listed in Table 4.

The volume we obtain for the Green Tuff Formation ( $\left.0.28 \mathrm{~km}^{3} \mathrm{DRE}\right)$ is lower than previous estimates. This is largely due to the fact that our volume calculations do not take into account caldera fills. These are speculative for all pre-Green Tuff Formations and in order to treat all units equally we have excluded this also for the Green Tuff. Our volume for the Mordomo Formation is lower than previous estimates because a lower average thickness has been calculated (see fence diagram and distribution map: Figure 4). For all other formations, our volume estimates are higher than previous estimates because of their larger aerial coverage (based on being erupted over most or all of the island).

The total onshore volume of all nine ignimbrite-forming formations is $2.53 \mathrm{~km}^{3} \mathrm{DRE}$. Individual eruptions range from 0.003 to $0.64 \mathrm{~km}^{3} \mathrm{DRE}$ (Table 4), which is relatively small compared to ignimbrite-forming eruptions of other peralkaline volcanoes with a similar-sized caldera (Gibson, 1970; Leat, 1984). Volumes of individual ignimbrite eruptions have generally been decreasing since the largest eruption (the 187 ka Polacca Formation), with the exception of the last ignimbrite at $46 \mathrm{ka}$ (Figure 26). However, this last eruption is best constrained whereas errors on volume estimates may generally be assumed to increase back in time. We stress that these are onshore volumes only, because we have no indication of how much was deposited under water. They are therefore minimum values and it may be reasonable to double or triple the onshore volumes to obtain 'true' volumes. Ignimbrites on Terceira (Azores) are thought to have a $0.3 \mathrm{~km}^{3}$ DRE onshore 
volume and 1-2 $\mathrm{km}^{3}$ DRE total volume (Gertisser et al., 2010) and might thus be the most similar to the Pantescan eruptions.

Table 4. New onshore volumes for ignimbrite formations (this study). Conversion from bulk density to dense rock equivalent (DRE) assumes a magma density of $2380 \mathrm{~kg} / \mathrm{m}^{3}$ (Rotolo et al., 2013).

\begin{tabular}{|c|c|c|c|c|}
\hline $\begin{array}{l}\text { Eruption-unit (area } \\
\text { covered) }\end{array}$ & $\begin{array}{l}\text { Average } \\
\text { thickness (m) }\end{array}$ & $\begin{array}{l}\text { Bulk density } \\
\left(\mathrm{kg} / \mathrm{m}^{3}\right)^{\mathrm{a}}\end{array}$ & $\begin{array}{l}\text { Volume }\left(\mathrm{km}^{3} \mathrm{DRE}\right) \\
\text { this study }\end{array}$ & $\begin{array}{l}\text { Volume (km³ DRE) } \\
\text { Rotolo et al., } 2013\end{array}$ \\
\hline $\begin{array}{l}\text { Green Tuff Formation } \\
\left(83 \mathrm{~km}^{2}\right)\end{array}$ & $4^{b}$ & 2000 & 0.28 & $\mathrm{n} / \mathrm{a}$ \\
\hline $\begin{array}{l}\text { Mordomo Formation } \\
\left(67 \mathrm{~km}^{2}\right)\end{array}$ & 3 & 1800 & 0.15 & 0.43 \\
\hline $\begin{array}{l}\text { Acqua Formation } \\
\left(67 \mathrm{~km}^{2}\right)\end{array}$ & 4 & 2000 & 0.23 & 0.19 \\
\hline $\begin{array}{l}\text { Cinque Denti } \\
\text { Formation }\left(59 \mathrm{~km}^{2}\right)\end{array}$ & 6 & 2000 & 0.30 & $0.29^{c}$ \\
\hline $\begin{array}{l}\text { Capre Formation } \\
\left(46 \mathrm{~km}^{2}\right)\end{array}$ & 10 & 2000 & 0.39 & $\mathrm{n} / \mathrm{a}$ \\
\hline $\begin{array}{l}\text { Arco Formation } \\
\left(63 \mathrm{~km}^{2}\right)\end{array}$ & 10 & 2000 & 0.53 & 0.34 \\
\hline $\begin{array}{l}\text { Polacca Formation } \\
\left(63 \mathrm{~km}^{2}\right)\end{array}$ & 12 & 2000 & 0.64 & 0.40 \\
\hline $\begin{array}{l}\text { Pozzolana Formation } \\
\left(\min .1 .5 \mathrm{~km}^{2}\right)\end{array}$ & 3 & 1800 & Min. 0.0034 & $\mathrm{n} / \mathrm{a}$ \\
\hline $\begin{array}{l}\text { Zinedi Formation (min. } \\
1.5 \mathrm{~km}^{2} \text { ) }\end{array}$ & 15 & $700^{d}$ & Min. 0.0066 & $\mathrm{n} / \mathrm{a}$ \\
\hline \multicolumn{5}{|c|}{ a From Rotolo et al., 2013.} \\
\hline \multicolumn{5}{|c|}{ b From Williams et al., 2014.} \\
\hline \multicolumn{5}{|c|}{ c This volume was mistyped in the original publication. } \\
\hline
\end{tabular}

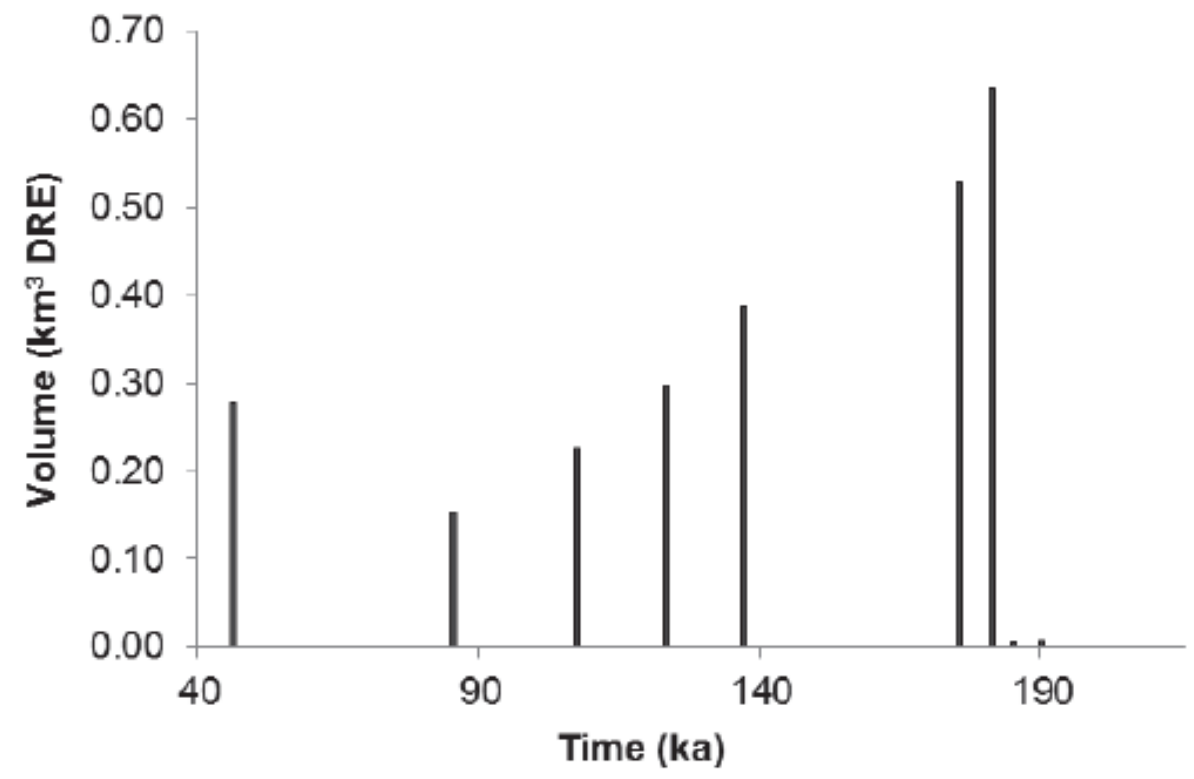

Figure 26. Time vs. (onshore) volume plot of the nine large eruptions on Pantelleria. Eruption sizes have been decreasing since the Polacca Formation (except Green Tuff Formation). Sources: see Table 1 and Table 4. 


\section{Conclusions}

- This study presents a complete pre-Green Tuff stratigraphy of Pantelleria volcano, characterizing its nine major ignimbrites and numerous interspersed local eruptions.

- Most of the ignimbrites are welded and contain lithic breccias. There is little record of sustained Plinian eruption columns related to these eruptions (e.g. no extensive pumice fall deposits) thus these eruptions are thought to be sub-Plinian in scale. Partial caldera collapse along the same faults may have occurred during five of the nine major eruptions (Green Tuff, Acqua, Cinque Denti, Capre and Polacca formations) contrary to common belief that the island underwent only two collapse events.

- Ignimbrite onshore volumes range from $<0.1$ to $0.6 \mathrm{~km}^{3} \mathrm{DRE}$, though due to Pantelleria's small size these should be considered minima.

- Localised eruptions, mostly on or near caldera faults, have produced small ignimbrites, pumice falls and lavas and have occurred throughout the entire $\geq 324$ kyr volcanic history. Their dispersal is limited and does not exceed several hundred metres. They may be cone or shieldshaped.

- $\quad$ The volcano has produced widespread welded ignimbrites only in the second half of its subaerial eruptive history (i.e. $<187 \mathrm{ka}$ ) but there is no evidence for temporal cyclicity in volcanic activity and the repose period varies from a few thousand to $\sim 40 \mathrm{kyr}$. Although radioisotopic analyses on post-Green Tuff eruptions suggesting waning activity since $\sim 14 \mathrm{ka}$, we caution against considering the current period as volcanologically different from any other inter-ignimbrite time in the last 200 kyr and therefore we cannot assume that no large, catastrophic eruption will occur in the future. However, we stress that an eruption is not expected imminently.

\section{Acknowledgements}

N.J.J. gratefully acknowledges funding from the German Academic Exchange Service, Geological Society of London, Mineralogical Society of Great Britain and Ireland, Geologists' Association, Quaternary Research Association, Volcanic and Magmatic Studies Group and the Department of Geology at the University of Leicester. Help during one of numerous field campaigns was provided by Leanne Gunn, Sally Smith, Capitano Trutz, Ellen McGowan, Joe McGrath, Thomas Jones, Fay McDermott, Laura Wilson, Catherine Russell, Stuart Hatter, Logan Gregory and Christa \& Peter Jordan. We recognise contributions from Leanne Gunn and Sally Smith who undertook undergraduate dissertations at the University of Leicester. Sample 11 is from the Master's project of Joe McGrath. 
Basell, L.S. (2008). Middle Stone Age (MSA) site distributions in eastern Africa and their relationship to Quaternary environmental change, refugia and the evolution of Homo sapiens. Quaternary Science Reviews, 27, 2484-2498.

Branney, M.J., Barry, T.L. and Godchaux, M. (2004). Sheathfolds in rheomorphic ignimbrites. Bulletin of Volcanology, 66, 485-491.

Branney, M.J. and Kokelaar, B.P. (2002). Pyroclastic density currents and the sedimentation of ignimbrites. Geological Society Publishing House, Bath (UK).

Civetta, L., Cornette, Y., Gillot, P.Y. and Orsi, G. (1988). The eruptive history of Pantelleria (Sicily channel) in the last $50 \mathrm{ka}$. Bulletin of Volcanology, 50, 47-57.

Civetta, L., Cornette, Y., Crisci, P.Y., Orsi, G. and Requejo, C.S. (1984). Geology, geochronology and chemical evolution of the island of Pantelleria. Geological Magazine, 121, 541-562.

Claessens, L., Veldkamp, A., Schoorl, J.M., Wijbrans, J.R., van Gorp, W. and Macdonald, R. (2016). Large scale pantelleritic ash flow eruptions during the Late Miocene in central Kenya and evidence for significant environmental impact. Global and Planetary Change, 145, 30-41.

Cole, J.W., Milner, D.M. and Spinks, K.D. (2005). Calderas and caldera structures: a review. EarthScience Reviews, 69, 1-26.

Coltelli, M., Cavallaro, D., D’Anna, G., D’Alessandro, A., Grassa, F., Mangano, G., Patanè, D. and Gresta, S. (2016). Exploring the submarine graham bank in the sicily channel. Annals of Geophysics, 59.

Cornette, Y., Crisci, G.M., Gillot, P.Y. and Orsi, G. (1983). Recent Volcanic History of Pantelleria - a New Interpretation. Journal of Volcanology and Geothermal Research, 17, 361-373.

Di Genova, D., Romano, C., Hess, K.-., Vona, A., Poe, B.T., Giordano, D., Dingwell, D.B. and Behrens, H. (2013). The rheology of peralkaline rhyolites from Pantelleria Island. Journal of Volcanology and Geothermal Research, 249, 201-216.

Di Muro, A., Rosi, M., Aguilera, E., Barbieri, R., Massa, G., Mundula, F. and Pieri, F. (2008). Transport and sedimentation dynamics of transitional explosive eruption columns: The example of the $800 \mathrm{BP}$ Quilotoa plinian eruption (Ecuador). Journal of Volcanology and Geothermal Research, 174, 307-324.

Di Muro, A., Neri, A. and Rosi, M. (2004). Contemporaneous convective and collapsing eruptive dynamics: The transitional regime of explosive eruptions. Geophysical Research Letters, 31, L10607 1-4.

Druitt, T.H. and Bacon, C.R. (1986). Lithic breccia and ignimbrite erupted during the collapse of Crater Lake Caldera, Oregon. Journal of Volcanology and Geothermal Research, 29, 1-32.

Druitt, T.H. (1985). Vent evolution and lag breccia formation during the Cape Riva eruption of Santorini, Greece. Journal of Geology, 93, 439-454. 
Druitt, T.H. and Sparks, R.S.J. (1982). A proximal ignimbrite breccia facies on Santorini, Greece. Journal of Volcanology and Geothermal Research, 13, 147-171.

Freundt, A. (1999). Formation of high-grade ignimbrites Part II. A pyroclastic suspension current model with implications also for low-grade ignimbrites. Bulletin of Volcanology, 60, 545-567.

Fulignati, P., Malfitano, G. and Sbrana, A. (1997). The Pantelleria caldera geothermal system: Data from the hydrothermal minerals. Journal of Volcanology and Geothermal Research, 75, 251-270.

Gertisser, R., Self, S., Gaspar, J.L., Kelley, S.P., Pimentel, A., Eikenberg, J., Barry, T.L., Pacheco, J.M., Queiroz, G. and Vespa, M. (2010). Ignimbrite stratigraphy and chronology on Terceira Island, Azores. Special Paper of the Geological Society of America, 464, 133-154.

Gianelli, G. and Grassi, S. (2001). Water-rock interaction in the active geothermal system of Pantelleria, Italy. Chemical Geology, 181, 113-130.

Gibson, I.L. (1970). A pantelleritic welded ash-flow tuff from the Ethiopian Rift Valley. Contributions to Mineralogy and Petrology, 28, 89-111.

Gioncada, A. and Landi, P. (2010). The pre-eruptive volatile contents of recent basaltic and pantelleritic magmas at Pantelleria (Italy). Journal of Volcanology and Geothermal Research, 189, 191-201.

Hutchison, W., Fusillo, R., Pyle, D.M., Mather, T.A., Blundy, J.D., Biggs, J., Yirgu, G., Cohen, B.E., Brooker, R.A., Barfod, D.N. and Calvert, A.T. (2016a). A pulse of mid-Pleistocene rift volcanism in Ethiopia at the dawn of modern humans. Nature Communications, 7.

Hutchison, W., Pyle, D.M., Mather, T.A., Yirgu, G., Biggs, J., Cohen, B.E., Barfod, D.N. and Lewi, E. (2016b). The eruptive history and magmatic evolution of Aluto volcano: new insights into silicic peralkaline volcanism in the Ethiopian rift. Journal of Volcanology and Geothermal Research, 328, 933.

Jordan, N. (2014). Pre-Green Tuff explosive eruptive history, petrogenesis and proximal-distal tephra correlations of a peralkaline caldera volcano: Pantelleria, Italy. PhD thesis. University of Leicester, UK.

Kuiper, K.F., Deino, A., Hilgen, F.J., Krijgsman, W., Renne, P.R. and Wijbrans, J.R. (2008).

Synchronizing rock clocks of earth history. Science, 320, 500-504.

Lanzo, G., Landi, P. and Rotolo, S.G. (2013). Volatiles in pantellerite magmas: A case study of the Green Tuff Plinian eruption (Island of Pantelleria, Italy). Journal of Volcanology and Geothermal Research, 262, 153-163.

Leat, P.T. (1984). Geological evolution of the trachytic caldera volcano Menengai, Kenya Rift Valley. Journal of the Geological Society, 141, 1057-1069.

Lowenstern, J.B. and Mahood, G.A. (1991). New data on magmatic H 2 O contents of pantellerites, with implications for petrogenesis and eruptive dynamics at Pantelleria. Bulletin of Volcanology, 54, 78-83. 
Mahood, G.A. and Hildreth, W. (1986). Geology of the peralkaline volcano at Pantelleria, Strait of Sicily. Bulletin of Volcanology, 48, 143-172.

Mahood, G.A. (1984). Pyroclastic rocks and calderas associated with strongly peralkaline magmatism. Journal of Geophysical Research, 89, 8540-8552.

Mattia, M., Bonaccorso, A. and Guglielmino, F. (2007). Ground deformations in the Island of Pantelleria (Italy): Insights into the dynamic of the current intereruptive period. Journal of Geophysical Research B: Solid Earth, 112.

Mellors, R.A. and Sparks, R.S.J. (1991). Spatter-rich pyroclastic flow deposits on Santorini, Greece. Bulletin of Volcanology, 53, 327-342.

Neave, D.A., Fabbro, G., Herd, R.A., Petrone, C.M. and Edmonds, M. (2012). Melting, differentiation and degassing at the Pantelleria volcano, Italy. Journal of Petrology, 53, 637-663.

Orsi, G., Ruvo, L. and Scarpati, C. (1991). The recent explosive volcanism at Pantelleria. Geologische Rundschau, 80, 187-200.

Orsi, G., Ruvo, L. and Scarpati, C. (1989). The Serra Della Fastuca Tephra at Pantelleria - Physical Parameters for an Explosive Eruption of Peralkaline Magma. Journal of Volcanology and Geothermal Research, 39, 55-60.

Palladino, D.M., Gaeta, M., Giaccio, B. and Sottili, G. (2014). On the anatomy of magma chamber and caldera collapse: The example of trachy-phonolitic explosive eruptions of the Roman Province (central Italy). Journal of Volcanology and Geothermal Research, 281, 12-26.

Parker, D.F. and White, J.C. (2008). Large-scale silicic alkalic magmatism associated with the Buckhorn Caldera, Trans-Pecos Texas, USA: Comparison with Pantelleria, Italy. Bulletin of Volcanology, 70, 403-415.

Pittari, A., Cas, R.A.F., Wolff, J.A., Nichols, H.J., Larson, P.B. and Martí, J. (2008). The Use of Lithic Clast Distributions in Pyroclastic Deposits to Understand Pre- and Syn-Caldera Collapse Processes: A Case Study of the Abrigo Ignimbrite, Tenerife, Canary Islands. In: Gottsmann, J.H. \& Martí, J. (Eds), Caldera Volcanism: Analysis, Modelling and Response. Developments in Volcanology. Elsevier, Amsterdam, pp. 97-142.

Rotolo, S.G., Scaillet, S., La Felice, S. and Vita-Scaillet, G. (2013). A revision of the structure and stratigraphy of pre-Green Tuff ignimbrites at Pantelleria (Strait of Sicily). Journal of Volcanology and Geothermal Research, 250, 61-74.

Rotolo, S.G., La Felice, S., Mangalaviti, A. and Landi, P. (2007). Geology and petrochemistry of the recent ( $<25 \mathrm{ka}$ ) silicic volcanism at Pantelleria Island. Bollettino della Societa Geologica Italiana, 126, 191-208.

Rotolo, S.G. and Villa, I.M. (2001). ${ }^{39} \mathrm{Ar}-{ }^{40} \mathrm{Ar}$ dating of an alkali-granite enclave from Pantelleria Island. Periodico di Mineralogia, 70, 269-269-275.

Salvador, A. (Ed). (1994). International Stratigraphic Guide: A guide to stratigraphic classification, terminology, and procedure. International Union of Geological Sciences and the Geological Society of America, Boulder, Colorado. 
Scaillet, B. and Macdonald, R. (2001). Phase relations of peralkaline silicic magmas and petrogenetric implications. Journal of Petrology, 42, 825-845.

Scaillet, S., Vita-Scaillet, G. and Rotolo, S.G. (2013). Millennial-scale phase relationships between icecore and Mediterranean marine records: insights from high-precision 40Ar/39Ar dating of the Green Tuff of Pantelleria, Sicily Strait. Quaternary Science Reviews, 78, 141-154.

Scaillet, S., Rotolo, S.G., La Felice, S. and Vita-Scaillet, G. (2011). High-resolution 40Ar/39Ar chronostratigraphy of the post-caldera $(<20 \mathrm{ka})$ volcanic activity at Pantelleria, Sicily Strait. Earth and Planetary Science Letters, 309, 280-290.

Speranza, F., Di Chiara, A. and Rotolo, S.G. (2012). Correlation of welded ignimbrites on Pantelleria (Strait of Sicily) using paleomagnetism. Bulletin of Volcanology, 74, 341-357.

Valentine, G.A. and Giannetti, B. (1995). Single pyroclastic beds deposited by simultaneous fallout and surge processes: Roccamonfina volcano, Italy. Journal of Volcanology and Geothermal Research, 64, 129-137.

Villari, L. (1974). The island of Pantelleria. Bulletin Volcanologique, 38, 680-724.

Walker, G.P.L. (1985). Origin of coarse lithic breccias near ignimbrite source vents. Journal of Volcanology and Geothermal Research, 25, 157-171.

Walker, G.P.L. (1983). Ignimbrite types and ignimbrite problems. Journal of Volcanology and Geothermal Research, 17, 65-88.

Walker, G.P.L. (1973). Explosive volcanic eruptions - a new classification scheme. Geologische Rundschau, 62, 431-446.

Washington, H.S. (1909). The submarine eruptions of 1831 and 1891 near Pantelleria. American Journal of Science, 27, 131-150.

Whitham, A.G. and Sparks, R.S.J. (1986). Pumice. Bulletin of Volcanology, 48, 209-223.

Williams, R., Branney, M.J. and Barry, T.L. (2014). Temporal and spatial evolution of a waxing then waning catastrophic density current revealed by chemical mapping. Geology, 42, 107-110.

Williams, R. (2010). Emplacement of radial pyroclastic density currents over irregular topography: the chemically-zoned, low aspect-ratio Green Tuff Ignimbrite, Pantelleria, Italy. PhD thesis. University of Leicester. DOI: 10.6084/m9.figshare.789054.v1.

Wolff, J.A. and Wright, J.V. (1981). Formation of the Green Tuff, Pantelleria. Bulletin of Volcanology, $44,681-690$.

Wright, J.V. (1980). Stratigraphy and geology of the welded air-fall tuffs of Pantelleria, Italy. Geologische Rundschau, 69, 263-291. 